\title{
Domestic Violence Torts: Righting a Civil Wrong
}

\author{
Camille Carey*
}

\section{INTRODUCTION}

Tort law defines what constitutes wrongful conduct in particular situations and dictates how tortfeasors legally compensate for their wrongful conduct. Sometimes tort law governs conduct in intimate relations, and other times it oversees the conduct of strangers or corporations. Tort law, especially personal injury law, has become an integral aspect of American society. It guides how individuals and companies conduct themselves and dictates how and when injured parties are compensated for their harms. Domestic violence harms have been conspicuously absent from the development of tort law. Domestic violence is pervasive, and its harms are serious. Pain and suffering, physical injuries, and even death arising out of abusive relationships are compensable through tort law, but these claims are rarely filed or discussed.

In its current iteration, tort law offers a number of well-suited but underused remedies for domestic violence victims. These common law claims were not created to provide redress for intimate partner violence, and historically were not allowed to do so. However, in contemporary times, tort claims are effective tools for legal recourse for domestic violence victims and should be pursued aggressively and frequently. ${ }^{1}$

\footnotetext{
* Associate Professor, University of New Mexico School of Law. I would like to thank participants in the faculty workshops at the University of New Mexico School of Law and the William S. Boyd School of Law, University of Las Vegas, the members of the Joint University of Colorado Law School and University of Denver Sturm College of Law Clinicians' Work in Progress Series, Max Minzner, Dawinder Sidhu, Ernesto Longa, Glenn Beard, and Robert Solomon. I would also like to thank Erin Joyce and KC Manierre for their research assistance.

1. I will refer to domestic violence victims as females throughout, given that the vast majority of domestic violence victims are women. PATRICIA TJADEN \& NANCY THOENNES, U.S. DEP'T OF Justice, Nat'L Inst. of Justice, NCJ 183781, Full Report of the Prevalence, InCidence, and Consequences of Violence Against Women: Findings from the National Violence AgAINST WOMEN SURVEY, at iv (2000), available at http://www.ojp.usdoj.gov/nij/pubssum/183781.htm (finding that "[a]pproximately 1.3 million women and 835,000 men are physically assaulted by an intimate partner annually in the United States"); JENNIFER L. TRUMAN, U.S. DEP'T of Justice, Bureau of Justice Statistics, NCJ 235508, Criminal Victimization, 2010, at 10 (2011), available at http://www.bjs.gov/index.cfm?ty=pbdetail\&iid=2224 (finding that "[t]he percentage of female victims $(22 \%)$ of intimate partner violence was about 4 times that of male
} 
The common law doctrines of chastisement, coverture, and spousal immunity historically shielded abusers from tort liability for domestic violence. Now that these sexist doctrines have lost their hold, tort law is ripe for use in the domestic violence context. Domestic violence victims can use existing common law and statutory tort causes of action-such as battery, assault, and intentional infliction of emotional distress - to sue their abusers for abusive conduct. Existing common law causes of action and a very small collection of newer tort claims provide easy avenues for development in this area of law. Through tort suits, victims can achieve financial compensation for harms, assume a position of control over legal claims addressing the abuse, experience both power and agency in an otherwise subordinating relationship, and seek deterrence of an abuser's abusive conduct.

This paper will discuss both traditional and specific tort claims that can be brought by domestic violence victims. It explores the dearth of domestic violence tort claims and looks at historical and contemporary factors causing the dearth of such claims. It sets forth the many benefits offered by tort law for domestic violence plaintiffs and proposes a paradigm shift in domestic violence lawyering to incorporate significantly more tort litigation.

Part I provides an overview of existing tort causes of action that are well suited for use by domestic violence victims. These tort actions include traditional common law claims like assault, battery, and intentional infliction of emotional distress. They also include several local and state tort claims for domestic violence and gender-motivated violence. The civil rights remedy under the Violence Against Women Act is discussed briefly to give context to the development of specific tort claims for gender-motivated and domestic violence. Part II describes the dearth of domestic violence tort claims and offers reasons why so few domestic violence tort claims have been brought. It examines how the common law history of chastisement, coverture, spousal immunity, and judicial obstinacy has barred these claims and affects the frequency of these claims today. This section also describes how insurance policy exclusions and other factors have contributed to the sparseness of domestic violence tort claims. Part III explores how tort claims can be productive avenues of relief for domestic violence victims. Positive potential outcomes for domestic violence plaintiffs include financial benefits, therapeutic benefits, and deterrence. Part IV discusses some shortcomings of tort law in remedying domestic violence harms. Part V proposes a paradigm shift in legal approaches to domestic violence, with

victims (5\%)"). 
domestic violence tort law occupying a more significant role.

\section{II: TORT CLAIMS FOR DOMESTIC VIOLENCE VICTIMS: COMMON LAW TORTS, VAWA, AND LOCAL AND STATE CLAIMS FOR DOMESTIC OR GENDER-RELATED VIOLENCE}

\section{A. Common Law Claims}

Pursuing common law tort claims should become a prominent approach within domestic violence law, leading a paradigm shift in how law can be used to combat abuse. Tort claims offer ready-made remedies that can provide meaningful financial and emotional benefits to domestic violence victims. Physical violence, sexual abuse, mental abuse, and other abusive behaviors in domestic violence relationships often create liability in tort. Common law torts, including negligence, recklessness, and especially intentional torts, can provide domestic violence victims with benefits not necessarily offered by other legal actions.

Intentional torts are effective vehicles for seeking redress for domestic violence harms. The types of abuse frequently perpetrated in domestic violence relationships tend to meet the elements of intentional torts, and thus many acts of domestic violence are actionable. The most pertinent causes of action for domestic violence harms include battery, assault, false imprisonment, and intentional infliction of emotional distress. Each will be addressed in turn.

\section{Battery}

A battery occurs when the defendant intends to make harmful or offensive bodily contact with the plaintiff, the plaintiff does not consent to the contact, and harmful or offensive contact results. ${ }^{2}$ The defendant need not intend the particular type of harm that results. ${ }^{3}$ For instance, the

2. Dan B. Dobbs, The Law of TorTs 52-53 (West Group 2000); Restatement (SeCOND) OF TORTS $\S 13$ (1965) ("[Harmful Contact:] An actor is subject to liability to another for battery if (a) he acts intending to cause a harmful or offensive contact with the person of the other or a third person, or an imminent apprehension of such a contact, and (b) a harmful contact with the person of the other directly or indirectly results." (emphasis added)); Id. § 18(1) ("[Offensive Contact:] (1) An actor is subject to liability to another for battery if (a) he acts intending to cause a harmful or offensive contact with the person of the other or a third person, or an imminent apprehension of such a contact, and (b) an offensive contact with the person of the other directly or indirectly results." (emphasis added)).

3. Jurisdictions differ as to whether the intent required for battery requires "dual intent," that defendant intended to cause bodily contact and intended that the contact be harmful or offensive, or 
defendant is liable for battery even if he intends only an offensive contact but a harmful contact results. ${ }^{4}$ Battery can also occur when the defendant acts intending to cause apprehension of a battery, and harmful or offensive contact results. ${ }^{5}$

The tort of battery is recognized as primarily protecting two interests: an interest in physical integrity, i.e., freedom from harmful bodily contact, and a dignitary interest, i.e., freedom from offensive bodily contact. ${ }^{6}$ Offending "a reasonable sense of personal dignity" means that the contact "would offend the ordinary person" and would be "unwarranted by the social usages prevalent at the time and place at which it is inflicted."7

In the context of domestic violence, abuse often violates one or both of these protected interests. Physical abuse violates the victim's interest in her own physical integrity and the victim's inherent right to be free from physical harm. ${ }^{8}$ Physical violence, including any aggressive touching, by the abuser also violates the victim's dignitary interest. Protection from unwanted or offensive contact is an integral goal of the law of battery. ${ }^{9}$ Domestic violence victims share this same protection offered to other tort victims, but abusive physical contact is particularly offensive in domestic

"single intent," that defendant intended a bodily contact that turned out to be harmful or offensive. DoBBS, supra note 2, 58-59. Compare White v. Muniz, 999 P.2d 814, 815 (Colo. 2000) (en banc) (requiring dual intent), with Villa v. Derouen, 614 So. 2d 714, 717 (La. Ct. App. 1993) (requiring single intent). The Restatement (Third) of Torts failed to address or resolve this issue. RESTATEMENT (THIRD) OF TORTS: LIABILITY FOR PHYS. \& EMOT. HARM § 1 (2010) (“A person acts with the intent to produce a consequence if: (a) the person acts with the purpose of producing that consequence; or (b) the person acts knowing that the consequence is substantially certain to result."). Joseph H. King, The Torts Restatement's Inchoate Definition of Intent for Battery, and Reflections on the Province of Restatements, 38 PEPP. L. REV. 623 (2011). King provides: "[The § 1] definition is an umbrella one, providing an all-inclusive definition of what it means to 'intend' something. It simply defines the state of mind needed to support a finding that a defendant intended 'something' as a 'consequence.' But, before a person may be determined to have entertained the necessary intent for a specific tort, we have to also know what 'consequence' must have been intended for that tort. The Section 1 definition does not address that aspect of intent - the nature of the 'consequence' that must have been intended to support various traditional torts that require intent, such as battery." Id. at 624. See also Nancy J. Moore, Intent and Consent in the Tort of Battery: Confusion and Controversy, 61 AM. U. L. REV. 1585, 1595-96 (2012) (discussing "how a Third Restatement might best formulate intentional tort doctrine in cases involving either harmful or offensive battery," specifically intent requirements, given the "ambiguity of the relevant Second Restatement provisions").

4. See DoBBS, supra note 2, 58-59.

5. RESTATEMENT (SECOND) OF TORTS $\S § 13,18$ (1965).

6. Dominick R. Vetri, Tort LaW and Practice 643 (LexisNexis, 4th ed. 2011).

7. RESTATEMENT (SECOND) OF TORTS $§ 19 \mathrm{cmt}$. a (1965).

8. DoBBS, supra note 2, at 54 (noting that battery "vindicates the plaintiff's rights of autonomy").

9. Id. 
violence situations because it violates the trust that should be present in an intimate partner relationship and is generally part of a pattern of abuse that is aimed at subordinating and controlling the victim.

Common acts of domestic violence that constitute battery include: slapping, punching, kicking, choking, pushing, twisting and breaking limbs, burning, stabbing, mutilation, throwing the victim, or throwing objects at the victim. ${ }^{10}$ Abusers may push the victim down the stairs, out of a moving car, or against a wall, causing serious injury. ${ }^{11}$ Domestic violence perpetrators frequently use extreme violence against their partners, including extensive beatings, torture, and using weapons, such as knives and guns, to inflict serious injury or disfigurement and possibly even death. ${ }^{12}$

Sexual battery is also extremely common in domestic violence relationships. ${ }^{13}$ Domestic violence perpetrators engage in a wide range of behaviors that constitute actionable sexual battery. An abuser may physically force an intimate partner to have sex against her will. He may coerce her to have sexual relations through threats of additional violence or force her to have sex after being beaten or in front of her children. ${ }^{14}$ He may also force her to perform sex acts she does not want to perform, including oral or anal sex, sex with third parties, and sex with objects. He may also refuse to allow the victim to use contraception to protect against pregnancy and sexually transmitted diseases. ${ }^{15}$ Many states have statutory causes of action for rape and sexual battery. ${ }^{16}$ In the absence of a specific statute, a domestic violence plaintiff can file a common law claim for battery or sexual battery.

\section{Assault}

Many domestic violence plaintiffs also will be able to file claims for

10. Lenore E. Walker, The BATtered Woman 79 (1979); see generally id. at 78-106 (noting types of physical assaults the women studied experienced and detailing some of their stories).

11. Anne L. Ganley, Understanding Domestic Violence: Preparatory Reading for Participants, in Susan Schechter \& ANNe L. Ganley, Domestic ViolenCE: A National CuRriculum for FAMILY PRESERVATION PRACTITIONERS 7, 12 (Janet Carter ed., 1995).

12. Evan Stark, Coercive Control: The Entrapment of Women in Personal Life 242 (2007); Ganley, supra note 11, at 12.

13. See generally WALKER, supra note 10, at 107-126 (discussing sexual abuse in violent relationships and providing personal accounts of women who experienced sexual abuse).

14. Ganley, supra note 11, at 12.

15. Sara L. Ainsworth, Stormans, Inc. v. Selecky, 24 HASTINGS WOMEN's L.J. 303, 326 (2013).

16. Violence Against Women: LaW and Litigation $\S$ 17:11 (David Frazee et al. eds., 1998). 
assault. An assault occurs when the defendant acts intending to cause a harmful or offensive contact with the plaintiff or acts intending to cause an imminent apprehension of such a contact, and the plaintiff is put in imminent apprehension of a harmful or an offensive contact. ${ }^{17}$ Some courts require that this apprehension of a contact be reasonable, as opposed to allowing for a claim based on actual apprehension. ${ }^{18}$ Threats by words alone are insufficient to sustain a claim for assault "unless[,] together with other acts or circumstances[, the threats] put the [plaintiff] in reasonable apprehension of an imminent harmful or offensive contact. . . ."19

Assault is extremely common in abusive relationships. Abusers seek to control their partners through threats of violence and intimidation. In one study conducted in Pittsburgh, 97\% of the participants reported that they had been threatened by their abusive spouses. ${ }^{20}$ Sixty-one percent of these victims indicated that they had been threatened "often." 21 Abusers commonly make verbal threats, threatening to kill the intimate partner and also often threatening to commit suicide after doing so. Threats are also made through conduct, such as displaying weapons, stalking, driving recklessly with the victim in the vehicle, or having someone else stalk the victim. $^{22}$

The conduct that incites imminent apprehension for assault in the domestic violence context can be subtle yet especially powerful for a particular victim given the ongoing power, control, and abusiveness of the relationship. Prior abuse creates a context for the victim's understanding of the meaning of the abuser's conduct. Yelling or threatening can more readily signify a true threat of harmful or offensive contact when the perpetrator has previously engaged in abusive behavior. ${ }^{23}$ Once a perpetrator has used violence either with that victim or another victim from a prior relationship, a threat of violence becomes much more actual and imminent.

17. ReSTATEMENT (SECOND) OF TORTS § 21(1) (1965) (“(1) An actor is subject to liability to another for assault if (a) he acts intending to cause a harmful or offensive contact with the person of the other or a third person, or an imminent apprehension of such a contact, and (b) the other is thereby put in such imminent apprehension.").

18. W. Page Keeton et al., Prosser and Keeton on the LaW of Torts 44 (W. Page Keeton ed., 5th ed. 1984).

19. RESTATEMENT (SECOND) OF TORTS $§ 31$ (1965).

20. Michael P. Johnson, A Typology of Domestic Violence: Intimate Terrorism, Violent Resistance, AND SituATIONAL COUPLE ViolenCe 26 (2008).

21. Id.

22. Ganley, supra note 11, at 12 .

23. See Mary Ann Dutton, Empowering And Healing the Battered Woman: A Model FOR ASSESSMENT AND INTERVENTION 18 (1992). 


\section{False Imprisonment}

Many domestic violence victims will have claims for false imprisonment. False imprisonment occurs when a defendant acts intending to confine the plaintiff within boundaries fixed by the defendant, the defendant's act directly or indirectly results in confinement of the plaintiff, and the plaintiff is conscious of the confinement or is harmed by it. ${ }^{24}$ Confinement for false imprisonment purposes may be achieved by physical force, threats of physical force, or other duress. ${ }^{25}$

False imprisonment is common in domestic violence situations. The acts constituting false imprisonment include locking the victim in a closet, room, or the home; forcing her to sit in a car, on the floor, or in one location for hours; prohibiting the victim from leaving the home; or refusing to give the victim keys to the home so that she is either automatically locked out if she leaves or is restricted from leaving without the ability to lock the door. ${ }^{26}$ Victims may also be able to establish a claim for false imprisonment based on an abuser's conduct during extended and ongoing sessions of abuse. It is not uncommon for physical attacks to continue for hours or days, with the abuser sometimes taking breaks to rest, sleep, or drink alcohol. ${ }^{27}$ In these circumstances, the victim is confined by the abuser's threat-already realized — of continued violence.

\section{Stalking}

Stalking is also a recognized civil claim in some jurisdictions. Often codified, many civil stalking provisions were enacted in response to celebrity stalking. ${ }^{28}$ These statutes, as well as common law claims for

24. Restatement (SECOND) OF TORTs § 35 (1965). See also id. § 36 (1965) (“(1) To make the actor liable for false imprisonment, the other's confinement within the boundaries fixed by the actor must be complete. (2) The confinement is complete although there is a reasonable means of escape, unless the other knows of it. (3) The actor does not become liable for false imprisonment by intentionally preventing another from going in a particular direction in which he has a right or privilege to go.").

25. Id. § 39 (1965) ("The confinement may be by overpowering physical force, or by submission to physical force."); id. $§ 40$ (1965) ("The confinement may be by submission to a threat to apply physical force to the other's person immediately upon the other's going or attempting to go beyond the area in which the actor intends to confine him."); id. § 40A (1965) ("The confinement may be by submission to duress other than threats of physical force, where such duress is sufficient to make the consent given ineffective to bar the action."). Confinement may also be achieved through asserted legal authority. Id. $\$ 41$ (1965).

26. STARK, supra note 12 , at 208.

27. Id. at 246.

28. 1 Thomson/West, Domestic Torts: Family Violence, Conflict and SeXual ABuse, 
stalking, are particularly helpful to domestic violence victims given the prevalence of stalking in abusive relationships. Stalking is second only to assault in abusive acts utilized by domestic violence perpetrators. ${ }^{29}$ Behaviors constituting stalking include: following the victim, maintaining close physical or visual proximity to her, and threatening or tormenting her. $^{30}$

\section{Intentional Infliction of Emotional Distress and Other Claims}

Domestic violence plaintiffs often also have viable claims for intentional infliction of emotional distress (IIED). A defendant is liable under IIED for emotional distress and any resulting bodily harm when he "intentionally or recklessly causes severe emotional harm" to the plaintiff through "extreme and outrageous conduct." ${ }^{31}$ Extreme and outrageous conduct is generally considered "conduct exceeding all bounds usually tolerated by decent society, of a nature which is especially calculated to cause, and does cause, mental distress of a very serious kind. ${ }^{, 32}$

In the domestic violence context, most successful IIED claims have been brought by plaintiffs who were threatened with or subjected to physical abuse. $^{33}$ These cases have generally involved intolerable or atrocious conduct that was intended to cause severe emotional harm to the plaintiff. ${ }^{34}$ Some courts have been reluctant to allow IIED claims against a spouse. ${ }^{35}$ IIED claims and negligent infliction of emotional distress claims, discussed below, recognize stand-alone emotional harm in which the plaintiff can recover for emotional harm without needing to prove physical injury. ${ }^{36}$

Other possible intentional tort claims in the domestic violence context include: invasion of privacy, ${ }^{37}$ defamation, ${ }^{38}$ and harassment. ${ }^{39}$ Domestic

\footnotetext{
REVISED EDITION 135 (2005).

29. STARK, supra note 12, at 256.

30. Violence Against Women: LAW AND Litigation, supra note 16, § 17:13.

31. RestatemENT (THIRD) OF TORTS: LIABILITY FOR PHYSICAL AND EMOTIONAL HARM $§ 46$ (2012).

32. KeETON ET AL., supra note 18, at 60 (citations omitted).

33. 1 THOMSON/WeST, supra note 28 , at 117 .

34. Id.

35. See infra Part III.B.

36. See infra notes 64-65. See also Restatement (THIRD) OF TORTS: Phys. \& EMOt. HaRm $\S 45 \mathrm{cmt}$. a (2012) ("Emotional harm encompasses a variety of mental states, including fright, fear, sadness, sorrow, despondency, anxiety, humiliation, depression (and other mental illnesses), and a host of other detrimental - from mildly unpleasant to disabling - mental conditions.").

37. Violence Against Women: LAW AND Litigation, supra note 16, § 17:15.

38. 1 THOMSON/WEST, supra note 28, at 143-46.
} 
violence plaintiffs may have viable claims for tortious infliction of a venereal disease. ${ }^{40}$ They may be able to seek damages for interference with educational opportunity ${ }^{41}$ or interference with custodial or visitation rights. ${ }^{42}$ Victims may have valid claims for economic torts such as interference with contractual relations if the abuser controlled the victim's access to money or otherwise prevented the victim from obtaining financial independence. ${ }^{43}$ Plaintiffs may also be able to sue for property torts like conversion ${ }^{44}$ or trespass to chattels ${ }^{45}$ if the abuser broke or sold the victim's property. ${ }^{46}$ The intentional torts listed here are by no means exhaustive. If a victim dies as a result of intentional or negligent acts by an abuser, surviving family members of a victim might have a claim for wrongful death. ${ }^{47}$ The victim's estate may also be able to continue any cause of action the victim had against the abuser as a survival action. ${ }^{48}$

\section{Intent for Intentional Torts and Recklessness and Negligence Claims}

With the exception of some wrongful death or survival actions, all of the aforementioned causes of action are intentional torts. Intentional torts require intent, which occurs when a tortfeasor purposely acts to accomplish a certain result, or, though not acting with a specific purpose, knows with a substantial certainty that his or her actions will bring about a certain result. ${ }^{49}$ Most acts of domestic violence involve sufficient intent to support an

\footnotetext{
39. Violence Against Women: LaW AND Litigation, supra note 16, § 17:12.

40. See 1 Kan. Law \& Prac., Family Law $§ 8: 32.4$ (discussing tortious infliction of venereal disease in Kansas).

41. Violence Against Women: LaW and Litigation, supra note 16, § 17:21.

42. Id.; William B. Johnson, Annotation, Liability of Legal or Natural Parent, or One Who Aids and Abets, for Damages Resulting from Abduction of Own Child, 49 A.L.R.4th 7 (1986); Joy M. Feinberg \& Lori S. Loeb, Custody and Visitation Interference: Alternative Remedies, 12 J. AM. ACAD. MATRIM. LAW. 271 (1994); William L. Hill, Note, Tort Recovery for Intentional Interference with Visitation Rights: A Necessary Alternative, 32 U. LOUISVILLE J. FAM. L. 657 (1994); Joseph R. Hillebrand, Note, Parental Kidnapping and the Tort of Custodial Interference: Not in a Child's Best Interests, 25 IND. L. REV. 893, 906-13 (1991).

43. Steven M. Pincus \& David N. Rosen, Fighting Back: Filing Suit Under the Violence Against Women Act, TRIAL, Dec. 1997, at 21, 24.

44. See generally RESTATEMENT (SECOND) OF TORTS §§ 222A, 229 (1965).

45. See generally id. $\$ 217$ (1965).

46. Pincus \& Rosen, supra note 43 , at 24.

47. See DoBBS, supra note 2, at 803-05, 807-15.

48. Id. at $805-07$.

49. Id. at 48; RESTATEMENT (THIRD) OF TORTS: Phys. \& EMOT. HARM $§ 1$ (2010) (“A person acts with the intent to produce a consequence if: (a) the person acts with the purpose of producing that consequence; or (b) the person acts knowing that the consequence is substantially certain to result.").
} 
intentional tort claim. Abusers act deliberately and intentionally, opening the way for victims to file intentional tort claims, as opposed to negligence actions. Domestic violence perpetrators use intentional acts to exert power over their partners. ${ }^{50}$ Their acts are intended "to punish, hurt, or control" their intimate partner. ${ }^{51}$ Their conduct is purposeful, seeking the compliance and control of the partner. ${ }^{52}$ Abusers have active control of their behavior and remain mindful and aware of their decisions even while committing violence. ${ }^{53}$ For each incident of abuse, domestic violence perpetrators give themselves permission to become abusive and choose how far to let themselves go. ${ }^{54}$ A true loss of control likely would result in much greater injury, even death, for the victim. ${ }^{55}$ An abuser's decision to use violence against the intimate partner is a choice. When abusers are in conflict with others - like co-workers or other family members - they do not choose to use violence against those individuals. ${ }^{56}$

Abusers are calculated in choosing to abuse, and often incorporate family privacy into their decisions. The private, isolated nature of the family provides increased opportunities for abuse that can play into this calculation. ${ }^{57}$ There is reduced social control in the private sphere of the family, and the cost to the perpetrator for abuse to an intimate partner is often significantly less than the cost of violence to someone outside the private sphere. ${ }^{58}$ The perpetrator may also decide that the rewards of abusing a partner are greater than the potential costs. ${ }^{59}$ Tort law assumes that individuals "stand back and consider the purposes they are attempting to realize through their acts, compare them with other possible purposes, and modify or abandon them." ${ }^{, 60}$ Abusers engage in such contemplation.

These calculations on the part of an abuser constitute sufficient culpability for intentional torts but also support torts requiring less

\footnotetext{
50. JOHNSON, supra note 20, at 13-17.

51. STARK, supra note 12, at 205.

52. Ganley, supra note 11, at 17-18.

53. Lundy Bancroft, Why Does He Do That?: Inside the Minds of Angry and CONTROLLING MEN 34-37 (2003).

54. Id. at 339 .

55. Richard J. Gelles, An Exchange/Social Control Theory, in THE DARK Side OF FAMILIES: CURRENT FAMILY ViolenCE RESEARCH 151, 159 (David Finkelhor et al. eds., 1983).

56. Ganley, supra note 11, at 23.

57. See generally Gelles, supra note 55, at 151-65 (discussing the social costs of violence to the abuser in the family as opposed to in public).

58. Id.

59. Id.

60. Ernest J. Weinrib, Understanding Tort Law, 23 VAL. U. L. REV. 485, 516 (1989).
} 
culpability such as recklessness $^{61}$ and negligence. ${ }^{62}$ Claims for recklessness (sometimes referred to as willful or wanton conduct) arise out of the types of violence discussed above, usually within the context of battery. Pursuing claims with lower levels of culpability may allow a plaintiff's case to proceed if the court fails to find the intent required for intentional torts. Additionally, pleading a case for negligence may also offer the plaintiff a better chance of recovery. While intentional tort actions usually are not covered by insurance policies, negligence actions typically are. ${ }^{63}$

Domestic violence victims may also be able to file claims for negligent infliction of emotional distress (NIED). NIED claims are primarily allowed in two situations: when an individual suffers emotional distress as a result of fearing for her own safety, ${ }^{64}$ and when an individual suffers emotional distress as a result of witnessing the serious bodily injury of a close family member. ${ }^{65}$ In domestic violence situations, liability for NIED for fearing for

61. A claim for recklessness requires a showing that the defendant engaged in conduct that created an unreasonable risk of harm to others and a high degree of risk or a risk of very serious harm. RESTATMENT (ThiRD) OF TORTS: PHYS. \& EMOT. HARM $§ 2$ (2010). The defendant must have been conscious of the risk and engaged in the conduct without concern for the safety of others. DoBbS, supra note 2, at 51. Cf. ReSTATEMENT (THIRD) OF TORTS: PHYS. \& EMOT. HARM § 2 (2010) ("A person acts recklessly in engaging in conduct if: (a) the person knows of the risk of harm created by the conduct or knows facts that make the risk obvious to another in the person's situation, and (b) the precaution that would eliminate or reduce the risk involves burdens that are so slight relative to the magnitude of the risk as to render the person's failure to adopt the precaution a demonstration of the person's indifference to the risk.").

62. Concurrently pursuing a lesser-included claim of negligence may allow for recovery if the court finds that the abuser's conduct was not intentional or reckless. To make a claim for negligence, the plaintiff must show: (1) that the defendant owed a duty of care to the plaintiff; (2) that the defendant breached that duty through his unreasonable and risky conduct; (3) that the defendant's conduct caused the plaintiff's harms; (4) that the defendant's conduct was the proximate cause of the plaintiff's harm, meaning there's a significant relationship between the conduct and the harm; and, (5) that the plaintiff suffered legally recognized harm. DOBBS, supra note 2, at 269. C.f., RESTATEMENT (THIRD) OF TORTS: PHYS. \& EMOT. HARM $\$ 3$ (2010) (“A person acts negligently if the person does not exercise reasonable care under all the circumstances. Primary factors to consider in ascertaining whether the person's conduct lacks reasonable care are the foreseeable likelihood that the person's conduct will result in harm, the foreseeable severity of any harm that may ensue, and the burden of precautions to eliminate or reduce the risk of harm.").

63. See infra part III.B.5.

64. This claim applies when the defendant's negligent conduct places the plaintiff in danger of immediate bodily harm and the plaintiff suffers severe emotional distress as a result of that danger. RESTATEMENT (THIRD) OF TORTS: PHYS. \& EMOT. HARM § 47 (2012) (“An actor whose negligent conduct causes serious emotional harm to another is subject to liability to the other if the conduct: (a) places the other in danger of immediate bodily harm and the emotional harm results from the danger....").

65. This claim, usually referred to as "bystander liability," provides a cause of action when an individual suffers serious emotional harm as a result of contemporaneously perceiving an event caused by the negligence of the actor which results in sudden serious bodily injury to a close family member. Restatement (ThiRd) OF TORTS: Phys. \& EMOT. HARM § 48 (2012) (“An actor who negligently causes sudden serious bodily injury to a third person is subject to liability for serious 
one's own safety arises frequently. NIED claims are viable only if the injuries are solely emotional. If there are physical injuries, the proper tort is battery, and emotional harm would be compensated as pain and suffering.

While beyond the scope of this paper, it should be noted that children may be able to pursue tort actions arising from domestic violence incidents. If a child is abused, the child may be able to file the same or similar common law claims as those available to domestic violence victims. Children who are not directly abused but who live in homes where domestic violence is present may also be able to pursue tort actions. If they witness abuse against a parent, they could file a negligence, reckless, or IIED claim. ${ }^{66}$ If they are injured accidentally incident to an act of domestic violence, they may be able to pursue negligence, recklessness, or intentional tort claims. ${ }^{67}$ However, many jurisdictions still maintain parental immunity for tort suits filed by a child against a parent. ${ }^{68}$

\section{Claims Against Third Parties}

It is also important to mention the possibility of filing domestic violence-related tort claims against third parties. Claims are sometimes available against municipalities and law enforcement agencies for failing to respond to a report of a restraining order violation or an incident of violence. ${ }^{69}$ Tort liability may also arise for third parties who have a "special relationship" that gives rise to a duty. The special relationship and its attendant duty can apply to doctors, ${ }^{70}$ therapists, and clergy members who

emotional harm caused thereby to a person who: (a) perceives the event contemporaneously, and (b) is a close family member of the person suffering the bodily injury."). Negligent infliction of emotional distress claims also arise in the "direct victim" context, usually arising from specific activities, such as mishandling human remains, or a special relationship between the parties, such as that between a physician and patient in limited scenarios. See RESTATEMENT (THIRD) OF TORTS: PHYS. \& EMOT. HARM $\S 47 \mathrm{cmt}$. b (2012) (noting that there can be liability "when an actor undertakes to perform specified obligations, engages in specified activities, or is in a specified relationship fraught with the risk of emotional harm"). A third type of NIED claim arises under a direct victim theory under assumed or independent duty. See DoBBS, supra note 2, at 848-51.

66. Clare Dalton, Domestic Violence, Domestic Torts and Divorce: Constraints and Possibilities, 31 New ENG. L. REV. 319, 340 (1997).

67. Id. at $340-41$.

68. Romualdo P. Eclavea, Annotation, Liability of Parent for Injury to Unemancipated Child Caused by Parent's Negligence-Modern Cases, 6 A.L.R.4th 1066, § 3 (1981).

69. See ViOLENCE AGAinst WOMEn: LAW AND LitigAtion, supra note 16, § 17:18; 2 Thomson/West, Domestic Torts: Family Violence, Conflict And Sexual ABuse 26 (Revised ed. 2005).

70. See James T.R. Jones, Battered Spouses' Damage Actions Against Non-Reporting Physicians, 45 DePAUl L. REV. 191 (1996); James T.R. Jones, Kentucky Tort Liability for Failure to Report Family Violence, 26 N. KY. L. REV. 43 (1999). 
may have a duty to third parties, here domestic violence victims. ${ }^{71}$ Tort claims also may be pursued against owners and occupiers of land who fail to protect against the criminal acts of third parties. For instance, landlords may be liable for domestic violence torts occurring on rental property. ${ }^{72}$ In addition to suing abusers, victims can also bring suit against third parties for failure to provide reasonable care to protect them from the foreseeable criminal acts of an abuser. ${ }^{73}$ This has the potential to enhance the victim's recovery and encourage third parties to protect victims from harm when they are able to do so.

\section{B. Violence Against Women Act}

Congress acknowledged the importance of tort claims to domestic violence victims when it passed the Violence Against Women Act of 1994 (VAWA). ${ }^{74}$ VAWA created a federal civil rights cause of action for the broader category of gender-motivated violence, which included domestic violence. This provision of VAWA, or Section 13981, framed the new claim as protecting the civil rights of victims ${ }^{75}$ by protecting the right of all people to be free of violent crimes motivated by gender. ${ }^{76}$ To assert a claim under VAWA, a plaintiff had to show that she was a victim of a "crime of violence motivated by gender." "77 VAWA defined a "crime of violence" as conduct that would constitute a felony against a person or would constitute a felony against property if the conduct against the property presented a serious risk of physical injury to another person and meets the definition of certain state or federal offenses. ${ }^{78}$ To satisfy the requirement that the crime was motivated by gender, the plaintiff would have to show that the crime was committed "because of gender or on the basis of gender, and due, at

71. See Violence Against Women: Law and Litigation, supra note 16, § 17:18; 2 ThOMSON/West, supra note 69, at 26-37.

72. Tracy A. Bateman \& Susan Thomas, Annotation, Landlord's Liability for Failure to Protect Tenant from Criminal Acts of Third Person, 43 A.L.R.5th 207, § 4(a)-(e) (1996); Corey Mostafa, Comment, The Implied Warranty of Habitability, Foreseeability, and Landlord Liability for Third-Party Criminal Acts Against Tenants, 54 UCLA L. REV. 971 (2007); PREMISES LiABILITY 3d § 41:19 (Louis Lehr ed. 2011).

73. See Violence AgAinst WOMEN: LAW AND Litigation, supra note 16, § 17:19 (providing that "premises liability cases involving violence against women are based on claims of negligent security or dangerous conditions of the premises").

74. Violence Against Women Act of 1994, Pub. L. No. 103-322, Title IV, 108 Stat. 1796 (codified as amended in various sections of 8,18 and 42 U.S.C. (1994)).

75. Id. $\S 40302$ (codified at 42 U.S.C. $\$ 13981$ (1994)).

76. 42 U.S.C. $\$ 13981(b)$.

77. $§ 13981(\mathrm{c}) \&(\mathrm{~d})(1)$.

78. $\$ 13981(\mathrm{~d})(2)(\mathrm{A})$. 
least in part, to an animus based on the victim's gender. ..."79 Successful plaintiffs could obtain compensatory and punitive damages, injunctive and declaratory relief, and other relief deemed appropriate by the court presiding over the immediate case. ${ }^{80}$

The civil remedy was framed as a civil right for women, allowing women to vindicate their right to be free from gender-motivated violence. ${ }^{81}$ It was unclear when VAWA passed whether courts would interpret all domestic violence as a "crime of violence motivated by gender" and how courts would interpret which acts of domestic violence would constitute a violent act "because of gender or on the basis of gender" and "due, at least in part, to an animus based on the victim's gender." 82 While the VAWA civil rights claim was in effect, the majority of plaintiffs brought intentional tort claims with the civil rights claim. ${ }^{83}$ Court decisions on Section 13981 domestic violence claims that followed VAWA's passage affirmed that domestic violence cases could fall within the parameters of Section 13981. ${ }^{84}$

Unfortunately, the Supreme Court struck down the civil rights remedy created by VAWA in 2000 in United States v. Morrison. ${ }^{85}$ The Morrison Court held that Congress lacked authority under the Commerce Clause to enact the Section 13981 civil remedy. ${ }^{86}$ It found that gender-motivated violent conduct was noneconomic activity and that Congress's attempt to regulate that conduct could not sustain a Constitutional challenge based on the aggregate effect of gender-motivated violence on interstate commerce. ${ }^{87}$ The Court also found that the civil rights remedy could not be upheld on Equal Protection grounds under Section 5 of the Fourteenth Amendment. ${ }^{88}$

\footnotetext{
79. $§ 13981(\mathrm{~d})(1)$.

80. $§ 13981(\mathrm{c})$.

81. S. Rep. No. 103-138, at 44 (1993); H.R. Conf. Rep. No. 103-711, at 385-86 (1994).

82. Reva B. Siegel, "The Rule of Love": Wife Beating as Prerogative and Privacy, 105 YALE L.J. 2117, 2199-201 (1996).
}

83. Jennifer Wriggins, Domestic Violence Torts, 75 S. CAL. L. REv. 121, 132 n.57 (2001) [hereinafter Wriggins, Domestic Violence Torts] (reviewing the seventy-three reported VAWA decisions and finding that fifty-one of the decisions included an intentional tort claim).

84. Julie Goldscheid \& Risa E. Kaufman, Seeking Redress for Gender-Based BiascrimesCharting New Ground in Familiar Legal Territory, 6 MiCH. J. RACE \& L. 265, 273-83 (2001) (analyzing cases that interpreted when an act of violence was "gender-motivated" rather than "random"). See, e.g., Culberson v. Doan, 65 F. Supp. $2 d 701$ (S.D. Ohio 1999); Seaton v. Seaton, 971 F. Supp. 1188 (E.D. Tenn. 1997); Doe v. Doe, 929 F. Supp. 608 (D. Conn. 1996). See also Julie Goldscheid, Gender-Motivated Violence: Developing a Meaningful Paradigm for Civil Rights Enforcement, 22 HARV. WOMEN's L.J. 123, 145-58 (1999).

85. 529 U.S. 598 (2000).

86. Id. at 613 .

87. Id. at $613,617-19$.

88. Id. at 619-27. 
The Court rejected the argument that Congress could enact a private civil rights claim to remedy states' pervasive bias against victims of gendermotivated violence in state justice systems. ${ }^{89}$ The Court held that Congress's power under Section 5 to enact legislation to guarantee that no state shall deprive any person of "life, liberty or property, without due process of law," nor deny any person "equal protection of the laws," did not empower it to create a Section 13981 claim against a private individual, as the Fourteenth Amendment applies only to state action, and not to "merely private conduct, however discriminatory or wrongful." 90

\section{State and Local Claims for Domestic and Gender-Motivated Violence}

While still extremely rare, several states and one municipality have developed specific tort claims that apply to domestic violence victims, either statutorily or through common law. Some of these claims mirror the now extinct VAWA civil remedy. New Jersey and Washington recognize the tort of battered women's syndrome; New York City, Illinois, and California acknowledge gender-motivated violence claims; and California has enacted a specific tort of domestic violence. Each is addressed in turn. While not specifically discussed here, it is important to note that many jurisdictions also have hate crime statutes that create civil liability for gender-based bias crimes. $^{91}$

\section{New Jersey}

A New Jersey trial court allowed recovery under a novel civil domestic violence claim called "battered woman's syndrome." In Cusseaux $v$. Pickett, ${ }^{92}$ the plaintiff, Jean Marie Cusseaux, brought a civil tort claim for "battered-woman's syndrome" against her intimate partner, Wilson Pickett, Jr., with whom she had lived for about ten years. ${ }^{93}$ The plaintiff alleged that the defendant engaged in a continuous course of abuse and violence, including hitting her with his fists on repeated occasions, breaking her nose, hitting her with a heavy kitchen pot, and striking her with a large

89. Id. at $625-27$.

90. U.S. ConST. amend. XVI, §§ 1, 5; Morrison, 529 U.S. at 621 (citing Shelley v. Kraemer, 334 U.S. 1,13 (1948)).

91. See, e.g., 740 Ill. Comp. Stat. Ann. 82/10 (West 2013); Minn. Stat. AnN. § 611A.79 (West 2013); Neb. ReV. STAT. § 28-113 (West 2013); N.J. STAT. ANN. § 2A:53A-21 (West 2013); D.C. CODE $§ 22-3704$ (2013).

92. 652 A.2d 789 (N.J. Super. Ct. Law Div. 1995).

93. Id. at 789 . 
corningware dish. ${ }^{94}$ The Cusseaux court held that the plaintiff had a cognizable claim for battered-woman's syndrome and in doing so, created a unique domestic violence tort claim in the State of New Jersey. ${ }^{95}$ The court established that the elements of such a claim are:

1) involvement in a marital or marital-like relationship; and 2) physical or psychological abuse perpetrated by the dominant partner ... over an extended period of time; and 3) the aforestated abuse has caused recurring physical or psychological injury over the course of the relationship; and 4) a past or present inability [on the part of the victim] to take any action to improve or alter the situation unilaterally. ${ }^{96}$

The court used many of the arguments related to the use of battered women's syndrome as a defense in criminal cases ${ }^{97}$ in allowing a similarly named affirmative civil cause of action. ${ }^{98}$ Battered woman's syndrome as an affirmative tort claim was affirmed by the Appellate Division of the New Jersey Superior Court in the case of Giovine v. Giovine. ${ }^{99}$

\section{Washington}

Washington State also acknowledges a tort called "battered woman syndrome." A Washington State Superior Court allowed recovery in a "battered woman syndrome" case. ${ }^{100}$ In Jewett $v$. Jewett, the plaintiff Theresa Jewett filed an action for assault, battery, battered woman syndrome, IIED, and outrage — as well as claims for deceit/bigamy, negligent misrepresentation, breach of contract of marriage, abuse of civil legal process, and wrongful initiation of civil proceedings. ${ }^{101}$ Jewett alleged that the defendant Michael Jewett engaged in a calculated pattern of pervasive and ongoing severe emotional and physical abuse after the parties'

\footnotetext{
94. Id. at $789-90 \mathrm{n} .1$.

95. Id. at 793 .

96. Id. at 793-94.

97. See State v. Kelly, 478 A.2d 364 (N.J. Sup. Ct. 1984) (discussing battered women's syndrome as grounds for a self defense claim in a homicide case).

98. Cusseaux, 652 A.2d at 791-92, 794.

99. 663 A.2d 109, 114, 123-24 (N.J. Super. Ct. App. Div. 1995) (affirming the elements of battered woman's syndrome enumerated in Cusseaux v. Pickett but clarifying that underlying abusive acts in a battered woman's syndrome claim must fall within the standard statute of limitations), overruled on other grounds by Kinsella v. Kinsella, 696 A.2d 556 (N.J. Sup. Ct. 1997).

100. Jewett v. Jewett, No. 93-2-01846-5 (Wash. Super. Ct. Spokane Cnty. 1993).

101. Verified Complaint For Damages at 7-10, Jewett v. Jewett, No. 93-2-01846-5 (Wash. Super. Ct. Spokane Cnty. 1993); First Amended Complaint For Damages at 7-12, Jewett v. Jewett, No. 93-2-01846-5 (Wash. Super. Ct. Spokane Cnty. 1993); Plaintiff's Third Amended Complaint For Damages at 7-13, Jewett v. Jewett, No. 93-2-01846-5 (Wash. Super. Ct. Spokane Cnty. 1994).
} 
marriage. ${ }^{102}$ On one occasion, in retaliation for the plaintiff calling the police, the defendant hyperextended the plaintiff's head, resulting in permanent neck and upper back damage. ${ }^{103}$ On another occasion, the defendant threw the plaintiff down against a coffee table and then repeatedly hit her in the face until she lost consciousness. ${ }^{104}$ The injuries were so severe that the plaintiff required reconstructive surgery to reposition her cheekbone. ${ }^{105}$ These are just a few of the violent episodes set forth in the plaintiff's complaint.

The trial court denied the defendant's motion to dismiss the plaintiff's battered woman syndrome claim. ${ }^{106}$ The court took judicial notice of the "extreme form of dependence" that many domestic violence victims experience. ${ }^{107}$ It noted:

[The parties'] interaction encourages not only the continuance of the relationship but also the violence within it. Once caught in the cycle, traditional remedies under the law, including the right to file civil actions for assault, battery, and intentional infliction of emotional distress (outrage), for all practical purposes are not available because the statutes of limitations prevent the victim from fully asserting her rights. ${ }^{108}$

The court articulated the elements of this new tort of battered woman syndrome as follows:

(1) a pattern of volitional acts, which include physical acts and gestures, as well as statements, threats, or verbal utterances; (2) which is reasonably calculated to create fear or anxiety or to establish perceptions of fear or anxiety for the victim's self or family; (3) that is continuous in nature, and, occurs over a period of time; (4) that could reasonably have been foreseen to, and that in fact did cause; (5) physical injury, emotional distress, or a state of emotional dependency that renders a victim unable to effectively maintain an action against

102. Verified Complaint For Damages at 2, Jewett v. Jewett, No. 93-2-01846-5 (Wash. Super. Ct. Spokane Cnty. 1994).

103. Id. at $2-3$.

104. Id. at 4 .

105. Id.

106. Order Denying Defendant's Motion to Dismiss Petition for Battered Women's Syndrome Pursuant to CR 12(b)(6) at 4, Jewett v. Jewett, No. 93-2-01846-5 (Wash. Super. Ct. Spokane Cnty. 1994).

107. Id. at 1 .

108. Id. 
her abuser. ${ }^{109}$

The plaintiff Theresa Jewett was granted a default judgment on her claims, including the battered woman syndrome claim. ${ }^{110}$ She was awarded $\$ 127,316$ in damages through a stipulated judgment. ${ }^{111}$ The judgment was paid by the defendant's estate because the defendant died of a heart attack in Costa Rica during the pendency of litigation. ${ }^{12}$

\section{City and State Statutory Developments}

The Jewett court's decision to recognize this novel claim was, as in the New Jersey case of Cusseaux v. Pickett, a progressive and important step in the development of domestic violence tort law. Other jurisdictions have taken a different approach by creating gender-motivated violence claims, similar to the now defunct civil remedy provision of VAWA. New York City, Illinois, and California have adopted gender-motivated violence laws that cover but are not limited to injuries arising from domestic violence.

\section{New York City}

New York City enacted a provision addressing domestic violence entitled the Victims of Gender-Motivated Violence Protection Act. ${ }^{113}$ The provision, contained in the Civil Rights section of the Administrative Code, provides a private right of action to victims of gender-motivated violence against their perpetrators. ${ }^{114}$ To succeed under such a claim, a victim must show that she was a victim of a "crime of violence" and that the crime of violence was "motivated by gender." 115 The code defines a "crime of

109. Id. at 3. See also Brief Amicus Curiae of Spokane Legal Servs. at 19-20, Jewett v. Jewett, No. 93-2-01846-5 (Wash. Super. Ct. Spokane Cnty. 1994) (providing that the tort of "domestic violence," i.e. battered women syndrome, is defined by these five elements).

110. Stipulated Judgment on Default, Jewett v. Jewett, No. 93-2-01846-5 (Wash. Super. Ct. Spokane Cnty. 1996). The defendant's motion to vacte the judgment was denied. Order Denying Defendant's Motion to Vacate Order and Judgment, Jewett v. Jewett, No. 93-2-01846-5 (Wash. Super. Ct. Spokane Cnty. 1996).

111. Stipulated Judgment on Default at 2, Jewett v. Jewett, No. 93-2-01846-5 (Wash. Super. Ct. Spokane Cnty. 1996).

112. Jim Lynch, Woman Wins Abuse Lawsuit Jewett to Receive \$125,000 from Dead Spouse's Estate, THE SPOKESMAN REVIEW (Jan. 6, 1996), http://www.spokesman.com/stories/1996/jan/06/woman-wins-abuse-lawsuit-jewett-to-receive$125000 /$.

113. New York City, N.Y., Administrative Code $\S \S 8-901$ to 8-907 (2000).

114. Id. § 8-902.

115. Id. $\S \S 8-903,904$. 
violence" as "an act or series of acts that would constitute a misdemeanor or felony against the person" or "against property as defined in state or federal law if the conduct presents a serious risk of physical injury to another, whether or not those acts have actually resulted in criminal charges, prosecution, or conviction." 116 The law defines "crime of violence motivated by gender" as "a crime of violence committed because of gender or on the basis of gender, and due, at least in part, to an animus based on the victim's gender." 117 Upon successfully showing these two elements, victims can seek "compensatory and punitive damages," "injunctive and declaratory relief," "attorneys' fees and costs," and "other relief as a court may deem appropriate." 118

New York City's Gender-Motivated Violence Protection Act is not tailored to address intimate partner violence exclusively but certainly encompasses it. Domestic violence cases fit squarely within the parameters set forth by New York City's Gender-Motivated Violence Protection Act. The law's Declaration of Legislative Findings and Intent makes repeated reference to the findings and intent of Congress in passing the federal Violence Against Women Act (VAWA), ${ }^{119}$ including Congress's intention to aid domestic violence victims through VAWA's federal civil remedy. The Committee Report supporting passage of the Act also makes repeated reference to domestic violence. ${ }^{120}$

Before passing the bill, the New York City Council heard testimony positing that a claim for gender-motivated violence would provide a muchneeded remedy for domestic violence victims. This testimony stated that "[c]urrently there are no legal remedies that provide meaningful economic relief to victims of gender-based domestic violence in New York City for the

\footnotetext{
116. Id. § 8-903.

117. Id.

118. Id. § 8-904.

119. Id. § 8-902.

120. Comm. on Gen. Welfare Jointly with the Comm. on Women's IsSues, Comm. ReP. ON PROPOSED INT. NO. 752-A (Nov. 30, 2000), available at http://legistar.council.nyc.gov/LegislationDetail.aspx?ID=434516\&GUID=CE9A1F14-B559-470AAB90-40FE9754385C ("The pervasiveness of domestic violence is well documented. According to the Mayor's Management Report for Fiscal 2000, the Police Department made 23,935 family-related arrests for the year and there were 4,012 arrests for violations of orders of protection. Further, the police filed 252,902 domestic incident reports in fiscal 2000. (Advocates believe that since many domestic violence incidents are not reported, this figure does not reflect the true immensity of the domestic violence problem in New York City). During fiscal 1999, the Police Department reported 87 domestic violence-related homicides. However, as is noted in the legislative findings, various task forces and the United States Department of Justice have found a climate of hostility in court systems towards sexual assault and domestic violence claims.").
} 
injuries they incur as a result of domestic violence." ${ }^{\prime 21}$ All voting members of the City Council unanimously passed the Act on December 5, 2000, and the mayor signed the law into effect on December 19, 2000. ${ }^{122}$

The only published decision related to New York City's GenderMotivated Violence Protection Act is Cadiz-Jones v. Zambetti, ${ }^{123}$ which is based on intimate partner violence. In Cadiz-Jones, Ms. Cadiz-Jones sued her former fiancé Mr. Zambetti for physical abuse under a number of claims, including a gender-motivated violence claim under the Act. ${ }^{124}$ The main issue in the case was whether Ms. Cadiz-Jones's gender-motivated violence claim was barred by the statute of limitations or whether it was still valid because the Act applied retroactively. ${ }^{125}$

The Cadiz-Jones court clearly acknowledged that domestic violence fits within the cause of action provided by the Act. The court did not address whether domestic violence constitutes gender-motivated violence. Instead, it launched into the primary issues of the case, namely matters related to the statute of limitations and retroactivity. In its decision, the Cadiz-Jones court stated, "It is evident that the City Council's intent was to fill the gap as soon as Morrison was decided by restoring the availability of a private remedy for domestic violence victims in New York City. ..."126 The court specified that the Act does not create a "distinct "tort of domestic violence.","127

\section{Illinois}

Illinois also provides an avenue for domestic violence tort relief through its Gender Violence Act. ${ }^{128}$ While not limited to domestic violence, the Gender Violence Act is sufficiently broad to encompass domestic violence as well as other forms of gender-motivated violence and was drafted with

121. Cadiz-Jones v. Zambretti, No. 123772/00, 2002 WL 34697795, at *6 (N.Y. Sup. Ct. Apr. 9, 2002).

122. Cadiz-Jones, 2002 WL 34697795 , at $* 7$. Nearby Westchester County quickly followed New York City's lead when it established the Victims of Gender-Motivated Violence Protection Act. WestChester COUNTY, NY, LAWS OF WeSTCHESTER COUNTY ch. 701 (2001). Nearby Rockland County also followed suit. ROCKLAND COUNTY, NY, LAWS OF ROCKLAND COUNTY ch. 279 (2001).

123. Cadiz-Jones, 2002 WL 34697795. But c.f. Cordero v. Epstein, 869 N.Y.S.2d 725, 730-31 (N.Y. Sup. Ct. 2008) (dismissing a Gender-Motivated Violence Protection Act claim for sexual contact with a minor because the statute of limitations had run and there was no showing that the defendant had "demonstrated any hostility based on gender").

124. Cadiz-Jones, 2002 WL 34697795, at *2-3.

125. Id. at *3-8.

126. Id. at *7.

127. $I d$. at $* 8$.

128. 740 ILl. Comp. StAT. AnN. 82 / 1-20 (West 2013). 
domestic violence in mind. The Preamble to the Bill frames the proposed Act as one targeting domestic violence and sexual abuse. It states that studies have shown that "gender-related violence such as domestic violence, which is disproportionately visited upon women by men, ... [h] arms many women and children without being reported or prosecuted." 129 The Preamble goes on to say that "[i]t is documented that existing State and federal laws have not provided adequate remedies to women survivors of domestic violence." 130 Then it states that "[w]omen survivors of domestic violence oftentimes have found laws against domestic violence used against them by their batterers." ${ }^{\text {"131 }}$ With the bill so explicitly couched in terms of domestic violence, the Illinois legislature clearly meant for the Act to provide an avenue of tort relief for domestic violence victims. The Act states that gender-motivated violence, including domestic violence, is a form of sex discrimination that the Act seeks to remedy. ${ }^{132}$

The Illinois Act ties its definition of gender-related violence to the state's criminal definition of battery, defining "gender-related violence" as:

(1) One or more acts of violence or physical aggression satisfying the elements of battery under the laws of Illinois that are committed, at least in part, on the basis of a person's sex, whether or not those acts have resulted in criminal charges, prosecution, or conviction[; or] (2) [a] physical intrusion or physical invasion of a sexual nature under coercive conditions satisfying the elements of battery under the laws of Illinois, whether or not the act or acts resulted in criminal charges, prosecution, or conviction[; or] (3) [a] threat of an act described in item (1) or (2) causing a realistic apprehension that the originator of the threat will commit the act.

The Illinois Gender Violence Act provides that victims of gendermotivated violence may seek "injunctive relief, . . . actual damages, damages for emotional distress, or punitive damages," as well as "attorney's fees and costs" and "other appropriate relief.",134

\section{California}

California has established both a civil action for gender-motivated

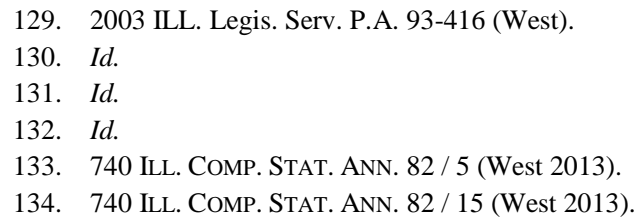


violence and a specific domestic violence tort. ${ }^{135}$ The California gendermotivated violence claim, known as the "[c]ivil action for damages arising from gender violence," largely mirrors the requirements of the Illinois Gender Violence Act. ${ }^{136}$ The California domestic violence tort claim, known as the "tort of domestic violence," provides civil relief specifically tailored to domestic violence as opposed to the broader category of gender violence. ${ }^{137}$ California Civil Code Section 1708.6 provides that a person is liable for the tort of domestic violence if "(1) [t] he infliction of injury upon the plaintiff result [s] from abuse," and "(2) [t] he abuse was committed by . . . a person having a relationship with the plaintiff as defined" by the statute. ${ }^{138}$ "Abuse" as required in the first element includes "intentionally or recklessly causing or attempting to cause bodily injury, or placing another person in reasonable apprehension of imminent serious bodily injury to himself or herself, or another." 139 The relationship required for tort liability can be that of a "spouse, former spouse, cohabitant, former cohabitant, or person with whom the suspect has had a child or is having or has had a dating or engagement relationship."

Under the California statute, a domestic violence tort plaintiff may recover "general damages, special damages, and punitive damages." these cases, courts are also authorized to grant "equitable relief, an injunction, costs, and any other relief that the court deems proper, including

135. CAL. CIV. CODE $\S \S 52.4,1708.6$ (West 2011).

136. CIV. $\S 52.4$. Section 52.4 provides in relevant part: “(a) Any person who has been subjected to gender violence may bring a civil action for damages against any responsible party. The plaintiff may seek actual damages, compensatory damages, punitive damages, injunctive relief, any combination of those, or any other appropriate relief. A prevailing plaintiff may also be awarded attorney's fees and costs. (b) An action brought pursuant to this section shall be commenced within three years of the act, or if the victim was a minor when the act occurred, within eight years after the date the plaintiff attains the age of majority or within three years after the date the plaintiff discovers or reasonably should have discovered the psychological injury or illness occurring after the age of majority that was caused by the act, whichever date occurs later. (c) For purposes of this section, "gender violence," is a form of sex discrimination and means any of the following: (1) One or more acts that would constitute a criminal offense under state law that has as an element the use, attempted use, or threatened use of physical force against the person or property of another, committed at least in part based on the gender of the victim, whether or not those acts have resulted in criminal complaints, charges, prosecution, or conviction[; or] (2) A physical intrusion or physical invasion of a sexual nature under coercive conditions, whether or not those acts have resulted in criminal complaints, charges, prosecution, or conviction." Id.

137. CIV. $\$ 1708.6$.

138. CIV. $\$ 1708.6(a)$.

139. Cal. Penal Code $\S 13700$ (a) (West 2005).

140. Id. $\S 13700(\mathrm{~b})$.

141. CIV. $\$ 1708.6(\mathrm{~b})$ 
reasonable attorney's fees." ${ }^{\text {142 }}$ The California legislature recognized the importance of tort recovery for domestic violence victims. Its findings include that " $[\mathrm{t}]$ hese acts merit special consideration as torts, because the elements of trust, physical proximity, and emotional intimacy necessary to domestic relationships in a healthy society makes participants in those relationships particularly vulnerable to physical attack by their partners." 143 The California courts have supported domestic violence tort claims, ${ }^{144}$ and the California legislature has created a special statute of limitations for domestic violence plaintiffs. ${ }^{145}$

These state and local causes of action, which aim to provide meaningful civil remedies to domestic violence victims, are good foundational efforts in the area of domestic violence torts. While this paper argues for the use of existing tort remedies, domestic violence specific tort claims could provide victims with even greater recovery. ${ }^{146}$ Under such claims, courts could

142. CIV. $\S 1708.6(\mathrm{c})$.

143. 2002 Cal. Legis. Serv. Ch. $193 \S 1$ (b) (West). The legislature also found that "acts of violence occurring in a domestic context [were] increasingly widespread," and, "[t]he purpose of this act [was] to enhance the civil remedies available to victims of domestic violence in order to underscore society's condemnation of these acts, to ensure complete recovery to victims, and to impose significant financial consequences upon perpetrators." Id. § 1(a), (c).

144. See Cheng v. Casas, No. H034352, 2011 WL 882995 (Cal. Dist. Ct. App. Mar. 15, 2011) (unpublished decision) (affirming trial court's order awarding terminating sanctions against plaintiff in action for tort of domestic violence and other claims for negligence and intentional torts arising from domestic violence); Boblitt v. Boblitt, 118 Cal. Rptr. 3d 788 (Cal. Dist. Ct. App. 2010) (reversing and remanding to allow plaintiff to proceed on her tort of domestic violence claim that was dismissed pursuant to a motion for summary judgment in a divorce proceeding); Pugliese v. Superior Court, 53 Cal. Rptr. 3d 681 (Cal. Dist. Ct. App. 2007) (finding that domestic violence plaintiffs, including tort of domestic violence plaintiffs, are entitled to seek recovery for all acts of domestic abuse occurring during the domestic relationship so long as the litigant proves a continuing course of abusive conduct); Deal v. Deal, No. A105221, 2005 WL 388725 (Cal. Dist. Ct. App. Feb. 18,2005 ) (unpublished decision) (finding that plaintiff's child abduction allegations do not constitute a claim under the tort of domestic violence statute).

145. CAL. Civ. Proc. CodE $\S 340.15$ (West 2011).

146. See generally Rhonda L. Kohler, The Battered Women and Tort Law: A New Approach to Fighting Domestic Violence, 25 LoY. L.A. L. REV. 1025, 1031 (1992) (arguing that "the courts and legislatures should recognize a new tort of spousal abuse which would facilitate compensating women for mental and physical injuries inflicted by battering domestic partners"). Kohler offers guidance to courts and legislatures in creating and recognizing domestic violence tort claims, recommending that courts recognize a continuing tort of spousal abuse using the following elements: "(1) intentional acts; (2) of extreme and outrageous conduct; (3) of a continuous nature; (4) proximately causing; (5) physical injury or emotional distress." Id. at 1068. See also Sarah M. Buel, Access to Meaningful Remedy: Overcoming Doctrinal Obstacles in Tort Litigation Against Domestic Violence Offenders, 83 OR. L. REV. 945, 1019-25 (2004) (arguing for recognition of a domestic violence tort and describing the benefits of a specially designated domestic violence tort); Dalton, supra note 66, at 344-46 (proposing a new tort of "partner abuse," incorporating "the entire history of combined physical and emotional abuse [into] a single claim"); Barbara Bennett Woodhouse, Sex, Lies, and Dissipation: The Discourse of Fault in a No-Fault Era, 82 GEO. L.J. 2525, 2566-67 (1994) (proposing a new "claim for marital tort or breach of spousal trust," providing recovery for 
compensate for emotional abuse that might not otherwise clearly be tortious and consider claims within the context of the emotional and physical abuse throughout the relationship. Some statute of limitations issues also may be alleviated by specific domestic violence tort claims that allow courts to examine long histories of abuse. States and municipalities should carefully craft statutes creating domestic violence tort causes of action, and courts should recognize common law claims for domestic violence similar to the battered woman's syndrome claim acknowledged by the New Jersey and Washington courts. ${ }^{147}$ Lawyers and plaintiffs should continue to bring novel claims for domestic violence torts to move this area of law forward. ${ }^{148}$

\section{REASONS FOR AND HISTORICAL PERSPECTIVES ON SCARCITY OF DOMESTIC VIOLENCE TORT CLAIMS}

\section{A. Scarcity of Claims}

Domestic violence tort claims represent a negligible percentage of all legal actions. Unfortunately there are no current studies as to the percentage of intentional tort cases involving intimate partners as opposing parties. Research results published in 1992 revealed a true dearth of intentional tort claims between intimate partners. ${ }^{149}$ Only fifty-three of 2600 state battery or assault cases that were reported between 1981 and 1990 were between adult parties in a domestic relationship. ${ }^{150}$ Just four such cases in federal court during the same time period were "between adult parties in a domestic relationship." ${ }^{151}$ Only eighteen of more than 6,000 reported intentional infliction of emotional distress claims in state and federal courts between

\footnotetext{
"physical, emotional, and economic injuries flowing from a spouse's misconduct," and acknowledging "a person's right to be free from egregious conduct related to sex and gender and to abuse of power in the home"); Melissa J. Peña, Note, The Role of Appellate Courts in Domestic Violence Cases and the Prospect of a New Partner Abuse Cause of Action, 20 REV. LiTIG. 503, 523 26 (2001) (proposing that state appellate courts adopt a cause of action for "partner abuse" which would "permit the victim to recover for all injuries occurring [throughout] the battering relationship").

147. See generally Anita Bernstein, How to Make a New Tort: Three Paradoxes, 75 Tex. L. REV. 1539 (1997) (discussing the successful creation of new torts generally).

148. See, e.g., Ziegler v. Ziegler, 28 F. Supp. 2d 601, 619 (E.D. Wash. 1998) (discussing whether the tort of domestic violence exists as a cause of action).

149. Douglas D. Scherer, Tort Remedies for Victims of Domestic Abuse, 43 S.C. L. REV. 543, 565 \& n.155 (1992) ("Among approximately 2600 reported state cases of battery, assault, or both, from 1981 through 1990, only fifty-three involved adult parties in domestic relationships.").

150. Id.

151. Id. at 565 .
} 
1958 and 1990 were based on facts indicating domestic violence. ${ }^{152}$ This means that only $0.3 \%$ of all intentional infliction of emotional distress cases studied arose from domestic violence incidents. In 2003, Professor Jennifer Wriggins conducted a Westlaw search attempting to quantify the number of domestic violence tort cases. ${ }^{153}$ Wriggins searched "in the Westlaw ALLCASES database for cases containing the words domestic violence and assault, battery, or intentional infliction of emotional distress." ${ }^{154}$ Out of the 6,138 citations she retrieved, only thirty-four cases involved intimate partners or former intimate partners in a domestic violence relationship. ${ }^{155}$ Some of these cases were independent tort claims, and some were added as counterclaims in divorce actions. ${ }^{156}$ Wriggins also searched the Civil Justice database of the National Crime Victim Bar Association, "which includes over 11,000 cases," and "found no domestic violence tort cases."157 Given the prevalence of domestic violence, these statistics reveal that domestic violence tort remedies have been very rarely pursued.

A look at historical developments in common law, combined with current policy restrictions in insurance coverage, reveals an environment inhospitable to domestic violence torts.

152. Id.

153. Jennifer B. Wriggins, Domestic Violence in the First-Year Torts Curriculum, 54 J. LEGAL EDUC. 511, 512-13 (2004) [hereinafter Wriggins, First-Year Torts] ("Recent searches in the Westlaw ALLCASES database for cases containing the words domestic violence and assault, battery, or intentional infliction of emotional distress, retrieved a total of 6,138 citations, but only 34 cases that contained tort claims arising from domestic violence in an intimate or formerly intimate relationship."); Jennifer B.Wriggins, Toward a Feminist Revision of Torts, 13 AM. U. J. GENDER SOC. POL'Y \& L. 139, 155 (2005) [hereinafter Wriggins, Feminist Revision of Torts].

154. Wriggins, First-Year Torts, supra note 153, at 512-13.

155. Id.

156. Id. at 513 n.8. Note eight provides: "Specifically, the search (July 30, 2003) for cases containing the words domestic violence and assault retrieved 4,408 citations, going back to 1961 . Only 22 contained tort claims arising from domestic violence in an intimate or formerly intimate relationship. The search (July 31, 2003) for cases containing the words domestic violence and battery retrieved 1,598 citations, 25 of which contained such tort claims. Of those 25,18 overlapped with cases retrieved with the domestic violence and assault search, so there was a total of 29 separate cases between the two searches. Similarly, the search (June 12, 2003) for cases mentioning domestic violence and intentional infliction of emotional distress retrieved 132 cases going back to 1982, only 13 of which dealt with the sort of claims I was seeking. Eight of these overlapped with cases in the other categories; in other words, there were 5 cases that did not fall in another category. Thus, the three searches turned up a total of 34 cases. Some of the 34 cases dealt with tort claims brought as counterclaims in a divorce, and some dealt with tort claims independent of divorces. The overall figure of 6,138 citations includes cases that appear in more than one category. These searches revealed thousands of criminal prosecutions pertaining to domestic violence." Id.

157. Id. at 513 . 


\section{B. Chastisement, Coverture, Spousal Immunity, Courts, and Insurance}

Historical and current forces in common law and insurance have conspired to prevent the development of domestic violence tort law. Under common law, the right of chastisement, the doctrine of coverture, spousal immunity, and courts' underhanded refusal to acknowledge the abrogation of spousal immunity have barred domestic violence tort claims. Additionally, insurance companies' current policy exclusions deny meaningful recovery to many domestic violence plaintiffs. Each of these factors contributing to the dearth of domestic violence tort claims will be examined.

\section{Chastisement}

Common law historically has fostered domestic violence. Early common law shielded perpetrators of domestic violence from civil liability for their tortious acts, especially abuse perpetrated against spouses. The doctrines of chastisement and coverture not only prevented women from pursuing civil claims against their husbands for abuse but also allowed and encouraged domestic violence in marriage. Specifically, men could beat, rape, or otherwise harm their wives, and the law protected this conduct.

The doctrine of chastisement granted men permission to engage in violent conduct toward their wives that today would constitute the underlying acts of domestic violence torts. Chastisement specifically permitted husbands to physically discipline or provide "correction" to their wives. ${ }^{158}$ This was justified because:

[A]s he is to answer for her misbehaviour, the law thought it reasonable to entrust him with this power of restraining her, by domestic chastisement, in the same moderation that a man is allowed to correct his servants or children; for whom the master or parent is also liable in some cases to answer. ${ }^{15}$

Under the right of chastisement, the husband could legally "chastise" his wife - or subject her to physical punishment - if she was not obedient to her husband or had otherwise engaged in "misbehavior." "160 The right of chastisement was limited to "reasonable bounds," and husbands were

158. 1 WiLliam BLACKSTONE, COMMENTARIES ON THE LAWS OF ENGLAND 444 (1771).

159. Id.

160. Siegel, supra note 82, at 2123; see generally id. at 2121-30 (detailing the right of chastisement). 
allowed to use violence against their wives so long as the right to do so lawfully and reasonably belonged to the husband for the correction of his wife. $^{161}$ The civil law permitted husbands the power to beat their wives severely with scourges and sticks in some situations and to use moderate chastisement in others. ${ }^{162}$

In the United States, the right of chastisement stopped being recognized in the 1870s. ${ }^{163}$ Several cases explicitly rejected the right of chastisement. In 1871, the Alabama Supreme Court in Fulgham v. State rejected a husband's right to chastise his wife. ${ }^{164}$ The Alabama court held that "the privilege ... to beat her with a stick, to pull her hair, choke her, spit in her face or kick her about the floor, or to inflict upon her like indignities, is not now acknowledged by our law." 165 The Massachusetts Supreme Court also rejected chastisement that same year in Commonwealth v. McAfee. ${ }^{166}$ In McAfee, the wife died as a result of severe domestic violence committed by her husband. ${ }^{167}$ The husband requested that the jury be instructed that he "had a legal right to administer due and proper correction and corporeal chastisement on his wife." 168 The judge refused to offer this instruction and instead instructed the jury that if the defendant's "unlawful blows" caused the wife's death, the jury should find the defendant guilty. ${ }^{169}$ The jury found the defendant guilty of manslaughter. ${ }^{170}$

\section{Coverture}

The doctrine of coverture also has severely stunted the development of domestic violence tort law. Coverture, rooted in the French covert-baron, meant that a married woman was "under the protection and influence of her husband, her baron, or lord." 171 Under the law of coverture, once married, a "husband and wife are one person in law," 172 as "the very being or legal

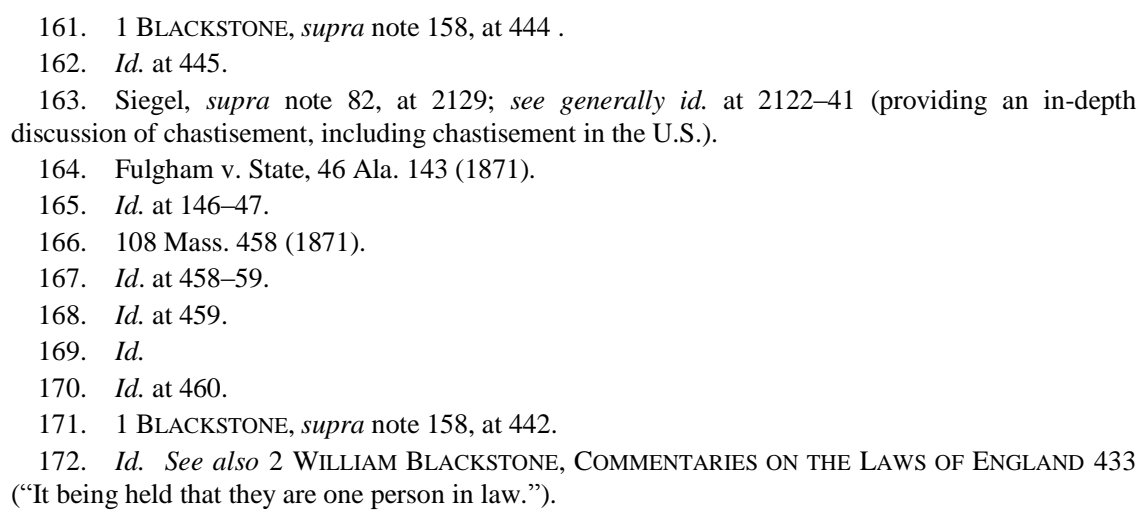


existence of the woman is suspended during the marriage, or at least is incorporated and consolidated into that of husband, under whose wing, protection, and cover, she performs every thing [sic]."173 The unity of the two was almost total, and a husband could not convey any property to or enter into any contract with his wife, as this "would be to suppose her separate existence," since "to covenant with her, would be only to covenant with himself." 174 A husband acquired the rights to and possession of a wife's personal and real property under the notion of the unity of person between husband and wife. ${ }^{175}$

The same concept of unity was applied to a wife's ability to bring an independent personal injury action. The law dictated that "[i]f the wife be injured in her person, or her property, she can bring no action for redress without her husband's concurrence, and in his name, as well as her own."176 Similarly, a wife could not be independently sued. ${ }^{177}$ Under the doctrine of coverture, neither the husband nor the wife could maintain a tort action against the other. ${ }^{178}$ Historically, "at common law the husband and wife were one, and the husband was that one." ${ }^{, 179}$ If a wife were to sue her husband for a domestic violence tort, the husband would have been joined as a plaintiff against himself and he would have received the recovery. ${ }^{180}$ Thus, under coverture, husbands committing abusive acts were protected from civil liability.

The common law principle of coverture made its way from England to early America, in large part through Blackstone's Commentaries on English law. Early American judges, lawyers, and lawmakers upheld the principle of unity under coverture as an ideal concept. ${ }^{181}$ American treatise writers "parroted" Blackstone, and coverture became the general rule. ${ }^{182}$

\footnotetext{
173. 1 BLACKSTONE, supra note 158 , at 442 .

174. Id.

175. 2 BLACKSTONE, supra note 172 , at 433-35.

176. 1 BLACKSTONE, supra note 158 , at 443.

177. Id

178. KeETON ET AL., supra note 18, at 901-02.

179. Id. at 902; William PROSSER, HANDBOOK OF THE LAW OF TORTS 859-64 (4th ed. 1971).

180. Restatement (SECOND) OF TORTS § 895F cmt. b (1979); Prosser, supra note 179, at 860.

181. Marylynn Salmon, Women and the LaW of Property in EARly America 14 (1986).

182. Hendrik Hartog, MAN AND Wife IN AMERICA: A History 116-17 (2000). See generally id. at 93-135 (discussing the law and tradition surrounding wives in early America); id. at 11-23 (describing the great variation in early American law based on individual colony and state approaches to regulation of marriage). See also SALMON, supra note 181, at 14 (noting that coverture - i.e. "unity of person"-as advertised by Blackstone, though often revised, was never abandoned).
} 
Coverture remained the norm until states began enacting Married Women's Property Acts around $1844 .{ }^{183}$ These Acts, which were also called Married Women's Acts or Emancipation Acts, were passed in all jurisdictions in the U.S. ${ }^{184}$ They were designed to provide married women with a separate legal identity and a right to hold their own property. ${ }^{185}$ These statutes to some extent gave married women a legal identity separate from their husbands. They permitted married women to sue and be sued without joining the husband as a party, to have separate ownership and control of their own property, and to be responsible for their own torts. ${ }^{186}$ They permitted married women to "maintain an action in her own name, for damages, against any person ... for any injury to her person or character, the same as if she were sole."

Courts limited married women's new rights to sue when it involved their husbands, however. Under Married Women's Property Acts, courts generally allowed wives to sue their husbands for torts arising from property interests. ${ }^{188}$ That is, a married woman could sue her husband for conversion, detention of chattels, fraud, trespass to land, waste, negligent damage to property, ejectment, or unlawful detainer. ${ }^{189}$ Most courts, however, refused to interpret the new Acts as allowing a married woman to sue her husband for torts arising from injury to the person. ${ }^{190}$ Instead, courts maintained de facto coverture for assault, battery, false imprisonment, malicious prosecution, defamation, and negligence claims by married women against their husbands. ${ }^{191}$ Courts rejected these claims even if the tortious conduct occurred "before the marriage... or where the [suit] brought after the marriage ... was terminated by separation, divorce, ... annulment, ... or death." 192

Courts developed new rationales for refusing to recognize claims, ${ }^{193}$

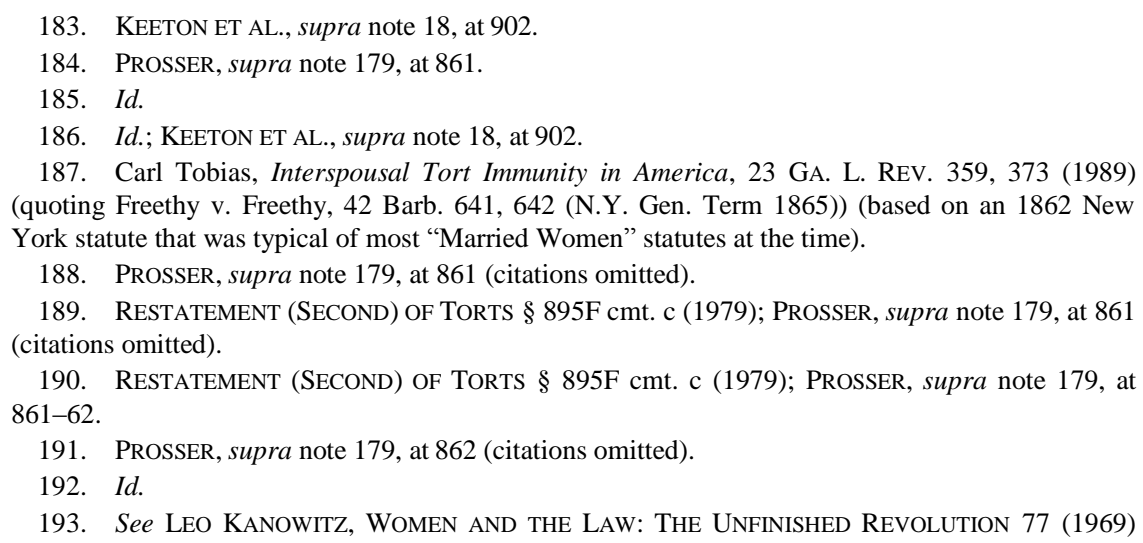


propounding a number of justifications for prohibiting suits between spouses for personal injury. ${ }^{194}$ A primary reason cited was that a tort suit would destroy the peace and harmony of the home and the marital relationship. ${ }^{195}$ Courts also reasoned that the availability of these suits would induce spouses to file fraudulent claims. ${ }^{196}$ Another justification was that courts would be burdened by excessive or trivial claims. ${ }^{197}$

\section{Spousal Immunity}

Thus, despite the Married Women's Property Acts, coverture lived on in tort law as the common law doctrine of spousal immunity. ${ }^{198}$ Spousal immunity was first recognized in the U.S. in the 1860s, with courts unanimously upholding the doctrine until $1913 .{ }^{199}$ In 1910, a split U.S. Supreme Court affirmed immunity between spouses for personal injury claims in Thompson v. Thompson. ${ }^{200}$ From 1914 to 1920 , all but seven jurisdictions recognized spousal immunity. ${ }^{201}$ From 1921 to 1940, substantially more jurisdictions maintained spousal immunity than abrogated it. ${ }^{202}$ Spousal immunity slowly lost hold until 1970, after which it became a minority rule. ${ }^{203}$ The Restatement (Second) allowed for tort suits between spouses in 1979. ${ }^{204}$ By 1988, spousal tort immunity had been largely eliminated in most jurisdictions. ${ }^{205}$ In those states that have retained spousal immunity, many have identified certain types of actions to which spousal immunity applies - generally for negligence, intentional torts, or vehicular torts. $^{206}$

(discussing rationales for interspousal tort immunity after the Married Women's Property Acts).

194. See generally Siegel, supra note 82, at 2161-70 (providing a discussion of the justifications offered by courts for maintaining spousal tort immunity).

195. ReStATEMENT (SECOND) OF TORTS § 895F cmt. d (1979); Prosser, supra note 179, at 122 (citation omitted); Tobias, supra note 187, at 389 (citations omitted).

196. RestatemEnT (SECOND) OF TORTS § 895F cmt. d (1979); KeEtON ET AL., supra note 18, at 902 (citations omitted); PROSSER, supra note 179, at 863.

197. Restatement (SECOND) OF TORTS $§ 895 \mathrm{~F} \mathrm{cmt.d}$ (1979); PROSSER, supra note 179, at 863 (citations omitted); Tobias, supra note 187, at 390 (citations omitted).

198. 1 THOMSON/WEST, supra note 28 , at 283-84.

199. Tobias, supra note 187 , at 359, 383-98.

200. Thompson v. Thompson, 218 U.S. 611 (1910).

201. Tobias, supra note 187 , at 383, 409-22.

202. Id. at 383,423 .

203. Id. at 435 .

204. RESTATEMENT (SECOND) OF TORTS § 895F(1) (1979).

205. 1 THOMSON/WeSt, supra note 28 , at 92-96.

206. 2 ThOMSON/West, supra note 69 , at app. B. For the status of spousal tort immunity, see Wayne F. Foster, Annotation, Modern Status of Interpersonal Tort Immunity in Personal Injury and 


\section{The Role of Courts in Limiting Domestic Violence Claims}

It is remarkable that courts across the country maintained spousal immunity for tort claims through most of the 20th century. ${ }^{207}$ Even in some jurisdictions in which spousal immunity has been eliminated, courts have underhandedly maintained the doctrine. To do so, courts have asserted policy reasons to retain spousal immunity for negligence actions and intentional torts. ${ }^{208}$ Most commonly, courts have set different standards for torts between spouses-thus effectively barring suits between spouses, especially in the area of emotional distress. ${ }^{209}$ In some instances, courts have even extended immunity to unmarried intimate partners. ${ }^{210}$

In Twyman v. Twyman, the Texas Supreme Court held that spouses could recover for intentional infliction of emotional distress only if the tortious conduct was not considered in dividing the marital estate. ${ }^{211}$ Dissenting in part, Chief Justice Phillips went beyond the majority's limitation of IIED claims by explicitly stating that he believed that spouses or former spouses could not use the cause of action for conduct occurring during marriage. ${ }^{212}$ He wrote:

In accordance with these sentiments, I believe that a tort which is grounded solely on a duty not to inflict emotional distress should not be cognizable in the context of marriage.

Married couples share an intensely personal and intimate relationship. When discord arises, it is inevitable that the parties will suffer emotional distress, often severe. ${ }^{213}$

Sheila Twyman alleged that William Twyman "intentionally and cruelly" attempted to coerce the plaintiff into performing deviant sexual acts during their marriage. ${ }^{214}$ She testified that he pursued these activities even though he knew she feared them because she had been raped at knifepoint before the marriage. ${ }^{215}$ The trial court found that the defendant in fact

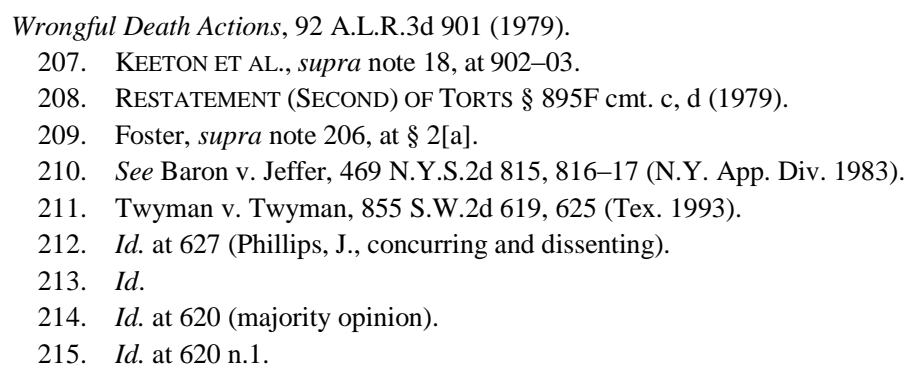


engaged in the alleged behavior. ${ }^{216}$ Nonetheless, Justice Phillips argued that the plaintiff should not recover simply because she was married to the defendant.

New York courts have more directly maintained spousal immunity by refusing to allow tort claims between spouses and other intimate partners. In Weicker v. Weicker ${ }^{217}$ the New York Court of Appeals denied the plaintiff wife's intentional infliction of emotional distress claim against her husband. The court did so based on the marital relationship between the parties. It reasoned:

Assuming that New York law now permits "recovery for the intentional inflicting of mental distress without proof of the breach of any duty other than the duty to refrain from inflicting it," strong policy considerations militate against judicially applying these recent developments in this area of the law to the factual context of a dispute arising out of matrimonial differences. ${ }^{218}$

In Baron v. Jeffer, ${ }^{219}$ the Appellate Division of the Supreme Court of the State of New York extended the Weicker prohibition against intentional infliction of emotional distress claims between spouses to a cohabiting couple. In Baron, the plaintiff girlfriend sought damages for assault and intentional infliction of emotional distress. ${ }^{220}$ The court upheld the lower court's decision to dismiss the assault claim based on a statute of limitations defense. ${ }^{221}$ The court then rejected the plaintiff's intentional infliction of emotional distress claim, citing the reasoning in Weicker. ${ }^{222}$ The court stated:

[I]t would be contrary to public policy to recognize the existence of this type of tort in the context of disputes, as here, arising out of the differences which occur between persons who, although not married, have been living together as husband and wife for an extended period of time (here, over two years). 223

In New York, intentional infliction of emotional distress claims between

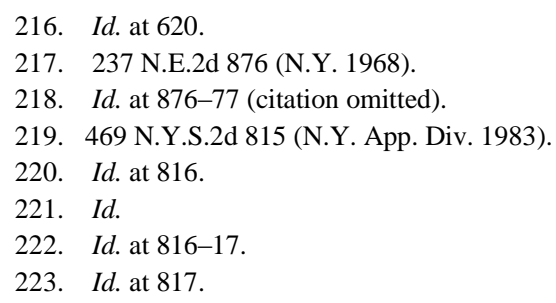


spouses and persons in marital-like relationships are still barred. ${ }^{224}$ By refusing to acknowledge intentional infliction of emotional distress claims in marital and marital-type relationships, courts in New York are continuing and expanding spousal immunity in modern times.

In New Mexico, courts are also fostering spousal immunity for intentional infliction of emotional distress claims by setting an insurmountable bar for claims between spouses. In Hakkila v. Hakkila, the New Mexico Court of Appeals set a very high bar for intentional infliction of emotional distress claims by one spouse against the other. ${ }^{225}$ The Hakkila court found that IIED claims must be viewed differently if arising out of a marital relationship. While acknowledging that spousal immunity had been abolished, the court articulated that there is only a "very limited scope for the tort in the marital context." 226 The court reasoned that:

Conduct intentionally or recklessly causing emotional distress to one's spouse is prevalent in our society. This is unfortunate but perhaps not surprising, given the length and intensity of the marital relationship. Yet even when the conduct of feuding spouses is not particularly unusual, high emotions can readily cause an offended spouse to view the other's misconduct as "extreme and outrageous." Thus, if the tort of outrage is construed loosely or broadly, claims of outrage may be tacked on in typical marital disputes, taxing judicial resources. ${ }^{22}$

E. Arnold Hakkila had perpetrated domestic violence throughout the marriage, including repeatedly physically assaulting Peggy Hakkila, insulting her privately and in front of others, and refusing to allow her to pursue schooling or hobbies. ${ }^{228}$ The court held that Mr. Hakkila's conduct

224. See Chen v. Fischer, 843 N.E.2d 723, 725 n.2 (N.Y. 2005) (agreeing that New York does not recognize intentional infliction of emotional distress claims by one spouse against another); Artache v. Goldin, 519 N.Y.S.2d 702, 706 (N.Y. App. Div. 1987) (dismissing an intentional infliction of emotional distress claim when parties lived together for fourteen years and had four children together); Murphy v. Murphy, 486 N.Y.S.2d 457, 459 (N.Y. App. Div. 1985) (allowing a claim for intentional infliction of emotional distress between parties formerly in an intimate partner cohabiting relationship because conduct on which claim was based occurred after the relationship had terminated); Ferreyr v. Soros, No. 109256/11, 2013 WL 388009 (N.Y. Sup. Ct. Jan. 22, 2013) (allowing a claim for intentional emotional distress to proceed because "the parties [sic] relationship, where the parties never lived together but at all times maintained separate households, falls well short of the marital type relationship that would bar plaintiff's claim"). But cf. Weisman v. Weisman, 485 N.Y.S.2d 570 (N.Y. App. Div. 1985) (holding that plaintiff spouse had properly plead her intentional infliction of emotional distress claim against her husband).

225. Hakkila v. Hakkila, 812 P.2d 1320 (N.M. Ct. App. 1991).

226. Id. at 1324 .

227. Id. at 1324-25.

228. Id. at 1321-22. 
was not sufficiently outrageous to sustain a claim for IIED. ${ }^{229}$

The court reasoned that "in determining when the tort of outrage should be recognized in the marital setting, the threshold of outrageousness should be set high enough ... that the social good from recognizing the tort will not be outweighed by unseemly and invasive litigation of meritless claims."230 Despite the repeated egregiousness of Mr. Hakkila's abusive conduct, the court insisted that "[i]t would be unfortunate if the law closed all the safety valves through which irascible tempers might legally blow off steam."231 Hakkila, which was decided in 1991, is still controlling in New Mexico. ${ }^{232}$

As exemplified in Hakkila, some courts continue to maintain de facto immunity in some types of domestic violence tort suits even when spousal immunity has been abrogated. ${ }^{233}$ Insurance companies, too, have joined these recalcitrant courts in perpetuating de facto immunity for domestic violence torts through their policy exclusions. ${ }^{234}$ Two insurance policy exclusions - intentional act exclusions and family member exclusions-act to deny recovery to domestic violence plaintiffs through liability insurance. $^{235}$

\section{The Lack of Insurance Coverage for Domestic Violence}

Intentional act exclusions deny coverage for any intentional acts

229. Id. at 1327.

230. Id. at 1326 .

231. Id. at 1324 (quoting Calvert Magruder, Mental and Emotional Disturbance in the Law of Torts, 49 HARV. L. REV. 1033, 1053 (1936)).

232. After Hakkila, the New Mexico Court of Appeals allowed a plaintiff to recover against his former wife for "fraud, breach of fiduciary duty, malicious abuse of process, and defamation" based on events that occurred during the marriage. Papatheofanis v. Allen, 242 P.3d 358, 360 (N.M. Ct. App. 2010). The court, citing Hakkila, said such recovery would be allowed because the claims did not involve marital misconduct, details of the couple's personal relationship, or issues regarding who was at fault for the dissolution of the marriage. Id. at 365 .

233. For instance, South Dakota still retains spousal immunity for intentional infliction of emotional distress. See State Farm Fire \& Cas. Co. v. Harbert, 741 N.W.2d 228 (S.D. 2007) (holding that state policy prohibits extension of insurance coverage to intentional infliction of emotional distress); Henry v. Henry, 534 N.W.2d 844, 847 (S.D. 1995) (holding that intentional infliction of emotional distress claims will not be allowed based on conduct during marriage but will be allowed based on conduct after divorce); Pickering v. Pickering, 434 N.W.2d 758, 761 (S.D. 1989) (stating that infliction of emotional distress claims are "unavailable as a matter of public policy when it is predicated on conduct which leads to the dissolution of a marriage").

234. Jennifer Wriggins, Interspousal Tort Immunity and Insurance "Family Member Exclusions": Shared Assumptions, Relational and Liberal Feminist Challenges, 17 WIS. WoMEN's L.J. 251, 252 (2002) [hereinafter Wriggins, Interspousal Tort Immunity and Insurance].

235. Id. at $252-53$. 
committed by the insured. ${ }^{236}$ Most homeowners, renters, and automobile insurance policies do not provide liability coverage for intentional acts under these intentional act exclusions. ${ }^{237}$ If a plaintiff sues for an intentional tort and the defendant has homeowners or renters insurance, the insurance company can successfully claim that the suit is not covered by the defendant's policy based on the intentional act exclusion. ${ }^{238}$ In this way, a plaintiff can be "worse off if the tort ... is classified as intentional rather than negligent."239 Thus, domestic violence victims are essentially barred from recovering under an insurance policy for a tort arising from domestic violence because most such torts are intentional. Victims may be tempted to argue that an injury resulted from the abuser's negligence in order to obtain compensation. ${ }^{240}$ However, when victims must negate the intentional nature of the abuser's act so that the harm will be covered by insurance, they are recreating the downplaying of abuse that is commonly present in abusive relationships. $^{241}$

Family member exclusions in insurance policies also deny coverage for many domestic violence torts. ${ }^{242}$ Standard homeowners insurance policies define insured individuals as anyone living in the home and exclude coverage for any harm caused by one insured against another. ${ }^{243}$ These family member exclusions, which are included in most policies, exclude all claims for harm caused by one family member to another, regardless of

236. Wriggins, Domestic Violence Torts, supra note 83, at 135.

237. Id. at 135-36. See also Wriggins, Interspousal Tort Immunity and Insurance, supra note 234, at 252; Wriggins, First-Year Torts, supra note 153, at 513.

238. Rick Swedloff, Uncompensated Torts, 28 GA. ST. U. L. REV. 721, 739-49 (2012); Wriggins, Domestic Violence Torts, supra note 83, at 136. See, e.g., Merrimack Mut. Fire Ins. Co. v. Coppola, 690 A.2d 1059, 1066 (N.J. Super. Ct. App. Div. 1997) (upholding the lower court's decision that insurance company was not obligated to defend or indemnify defendant for his acts of abuse against his former wife under a homeowners policy). See generally RESTATEMENT (THIRD) OF TORTS: PHYS. \& EMOT. HARM $\S 1 \mathrm{cmt}$. f (2010) ("[B]ecause the express and implied exclusions [for intentional torts] from the coverage provided by liability-insurance policies may not be completely congruent with tort-law categories, the proper interpretation of these policy provisions and public-policy doctrines is ultimately a matter for contract and insurance law, not tort law."); Hazel Glenn Beh, Tort Liability for Intentional Acts of Family Members: Will Your Insurer Stand By You?, 68 TenN. L. ReV. 1 (2000); Ellen S. Pryor, The Stories We Tell: Intentional Harm and the Quest for Insurance Funding, 75 TEX. L. Rev. 1721 (1997).

239. RestatemEnt (ThiRd) OF TORTs: PHys. \& EMOT. HARM $\S 5 \mathrm{cmt}$. a (2010).

240. Dalton, supra note 66 , at 341 .

241. Id

242. Wriggins, Domestic Violence Torts, supra note 83, at 137.

243. Id. See generally Martin J. McMahon, Annotation, Validity, Under Insurance Statutes, of Coverage Exclusion for Injury to or Death of Insured's Family or Household Members, 52 A.L.R.4th 18 (1987). 
whether the harm was accidental or intentional. ${ }^{244}$ Thus, if a wife sues a husband for injuries arising from domestic violence, the insurance policy will not cover the husband for the claim. ${ }^{245}$ The wife can only recover from the husband's assets or their marital assets, but only if there are any assets or sufficient assets. ${ }^{246}$ Some courts have struck down the family member exclusion, especially in the automobile insurance context. ${ }^{247}$ These family member exclusions were "designed with a view to protect . . . insurers from collusive suits." 248

States also participate in perpetuating immunity for domestic violence torts through regulation of insurance. State legislation controls certain aspects of insurance contracts and markets. ${ }^{249}$ Intentional act and family member exclusions, as supported by state regulation, operate to deny recovery to domestic violence plaintiffs, especially those suing abusers who are judgment proof or have few assets. ${ }^{250}$

Insurance policies, recalcitrant courts, and a long history of common law resistant to redress for intimate partner violence have created a void where domestic violence tort law might have developed but did not. During the times of chastisement, coverture, and spousal immunity, domestic violence plaintiffs did not have the benefit of a supportive movement to encourage them to challenge the laws that barred these claims. The domestic violence movement did not emerge until the 1970s. ${ }^{251}$ Spousal immunity became the minority rule in the 1970s as well. This could have been a time when domestic violence tort claims came to the fore. Instead,

244. Wriggins, First-Year Torts Curriculum, supra note 153, at 513.

245. Wriggins, Interspousal Tort Immunity and Insurance, supra note 234, at 252.

246. Wriggins, Domestic Violence Torts, supra note 83, at 137-38.

247. Wriggins, Interspousal Tort Immunity and Insurance, supra note 234, at 252-53 n.11.

248. Id. at 252 n.10 (citing Robert E. KEETON \& ALAN I. Widiss, INSURANCE LAW 393 § 4.9(c)(1) (1988)).

249. Wriggins, Interspousal Tort Immunity and Insurance, supra note 234, at 255.

250. Jennifer Wriggins proposes insurance reform that would help ensure that domestic violence plaintiffs satisfy tort judgments. Wriggins, Domestic Violence Torts, supra note 83. Under Wriggins's proposal, liability insurance would be a mandatory part of automobile liability insurance. $I d$. at 152. The insurance policy would cover domestic violence tort claims, and defendants would be required to reimburse insurers for payments made to satisfy domestic violence tort judgments. Id. These reformed insurance policies would also include "uninsured domestic violence tortfeasor" provisions in case the abuser is uninsured. Id. at 127,153 . If the defendant is uninsured, the plaintiff's recovery would be covered by the plaintiff's own uninsured domestic violence tortfeasor section of her policy. Id. at 152-54.

251. See generally SusAn Schechter, Women AND Male Violence: The Visions AND STRUGGLES OF THE BATTERED WOMEN's MOVEMENT 53-131 (1982) (discussing the foundations of the Battered Women's Movement); Elizabeth Pleck, Domestic Tyranny: The Making of Social Policy Against Family Violence from Colonial Times to the Present 182-200 (1987). 
the domestic violence movement was primarily focused on developing shelters and criminal justice interventions. ${ }^{252}$ In the meantime, insurance companies stepped in to maintain spousal immunity and expand immunity to non-married intimate partners through intentional act and family member exclusions. Very few domestic violence tort claims have emerged from this unfavorable history.

\section{Other Reasons for Scarcity of Domestic Violence Tort Claims}

In addition to the gendered history of common law and insurance exclusions, there are a number of other possible reasons that domestic violence tort suits are so rare. ${ }^{253}$

In general, intentional tort claims are infrequently pursued. The National Center for State Courts reports that tort claims in general comprise of only about $6 \%$ of all state court cases. ${ }^{254}$ Of these, automobile tort cases constitute the majority. ${ }^{255}$ Intentional tort claims constitute a small fraction of tort cases, with intentional torts comprising of as few as $2.9 \%$ of all tort claims in state courts in $1992 .{ }^{256}$ Intentional torts have also been largely omitted from tort doctrine and scholarship, with negligence and strict liability dominating. ${ }^{257}$ Torts including assault, battery, false imprisonment, and intentional infliction of emotional distress have received little attention from scholars and play an insignificant role in the field of torts generally. ${ }^{258}$ Instead, tort law "has been conceptualized as pertaining primarily to

252. See generally SCHECHTER, supra note 251, at 53-131.

253. For other explanations for the dearth of domestic violence tort cases, including reasons of privacy, see Buel, supra note 146, at 949-55.

254. Robert C. LaFountain ET al., National Center for State Courts, Examining the Work OF STATE COURTS: AN ANALYsis OF 2010 STATE Court Caseloads 3 (2012), http://www.courtstatistics.org/otherpages/ /media/microsites/files/csp/data\%20pdf/csp_dec.ashx. In 2008, new tort claims comprised $4.4 \%$ of all claims brought in state courts. ROBERT C. LaFountain et al., National Center for State Courts, Examining the Work of State Courts: AN ANAlysis OF 2008 State COURT CASEloAds 26 (2010), http://www.courtstatistics.org/other-pages/ /media/microsites/files/csp/ewsc-2008-online.ashx [hereinafter 2008 CASELOADS]. In 2007, such tort claims constituted $6 \%$ of all claims brought in state courts. Id.

255. 2008 CASELOADS, supra note 254, at 28 .

256. Steven K. Smith et al., Bureau of Justice Statistics, U.S. Dep’t of Justice, NCJ 153177, TORT CASES IN LARGE COUNTIES http://www.bjs.gov/content/pub/pdf/TCILC.PDF. Only $2.7 \%$ of civil jury cases that went to trial in state courts were intentional tort cases. CAROL J. DeFrances, Bureau of Justice Statistics, U.S. DeP'T OF Justice, NCJ 154346, Civil JuRy CASES AND Verdicts IN LARGe Counties 2 (1995), http://www.bjs.gov/content/pub/pdf/cjcavilc.pdf.

257. Wriggins, Feminist Revision of Torts, supra note 153, at 153.

258. Id. 
accidental injury that causes harm to strangers."259

\section{Financial Resources}

Financial resources play a large role in determining whether domestic violence torts suits are initiated. Representation in these cases is nearly impossible to secure through a legal services or nonprofit law office. Any legal services agency that receives funding through the federal Legal Services Corporation (LSC) is prohibited from engaging in certain types of activities and representation. One such restriction is that, with limited exceptions, the agency cannot pursue a fee generating claim, unless the claim has been either "rejected by the local lawyer referral service, or by two private attorneys[,] or [if] [n]either the referral service nor the two private attorneys" would provide a consultation without a fee. ${ }^{260}$ If the legal services office satisfies this requirement and accepts a fee-generating case, it must meet additional onerous paperwork and audit requirements. ${ }^{261}$

Additionally, legal services or nonprofit law offices that receive funding from the Legal Assistance for Victims ("LAV") Grant Program are prohibited from using any grant funds to support litigating domestic violence tort claims. ${ }^{262}$ The LAV Grant Program, which is maintained by the Office on Violence Against Women at the U.S. Department of Justice, is a primary funder of legal representation of domestic violence victims. ${ }^{263}$ This federal funding stream for domestic violence lawyering was created by the Violence Against Women Act of 1994 and was reauthorized in 2000, 2005, and 2013; it made domestic violence attorneys in legal services offices more commonplace. $^{264}$ Even though the grant requires that grantees address a "demonstrated need in their communities by providing services that promote the dignity and self-sufficiency of victims, improve their access to resources,

259. Id. See also Wriggins, First-Year Torts Curriculum, supra note 153, at 514.

260. 45 C.F.R. $\S 1609.3(a)(1)-(2)$ (2011).

261. § 1609.4. See also 1609 Fee-Generating Cases, LEGAL SERviCES CoRPORATION, OfFICE OF THE ATTORNEY GENERAL, https://www.oig.lsc.gov/aud/cs98/cs981609.htm (last visited Mar. 11, 2014).

262. OfFice on Violence Against Women, U.S. Dep't Of Justice, OMB No. 1122-0020, OVW Fiscal Year 2013 Legal Assistance For Victims Grant Program 10-11 (2013), http://www.ovw.usdoj.gov/docs/2013-lav-solicitation.pdf [hereinafter LAV 2013].

263. See id. at 3.

264. See Rhonda McMillion, Congress Moves to Reauthorize Laws Targeting Domestic Violence, Human Trafficking, A.B.A. JouRnAL (May 1, 2013, 12:30 AM), http://www.abajournal.com/magazine/article/congress_moves_to_reauthorize_laws_targeting_dome stic_violence_human_traffi/. 
and create options for victims seeking safety from perpetrator violence,",265 LAV grantees are prohibited from using LAV funds to pursue tort claims. ${ }^{266}$ The Program specifically prohibits using grant funds to support legal representation of victims in tort actions. ${ }^{267}$

\section{Attorney's Fees}

The system for payment of attorney's fees also diminishes the number of domestic violence tort suits. Under the "American rule" for attorney's fees, "the losing party is not required to pay the winning party's fees." 268 Generally plaintiffs pay their own attorney's fees. ${ }^{269}$ The plaintiff can either front the attorney's fees or seek representation on a contingency fee basis. If the case is taken on a contingency fee basis, the attorney is paid a percentage of the plaintiff's recovery. ${ }^{270}$ If the plaintiff does not prevail, the attorney is not compensated. ${ }^{271}$ In the domestic violence context, this means that the plaintiff must either pay the lawyer using her own resources or find a lawyer who is willing to take the case based on a calculation that the claim will prevail and provide sufficient recovery such that the lawyer's contingency fee will be sufficient. Very few domestic violence victims will have enough financial resources to pay an attorney to litigate a tort matter. Thus, whether a domestic violence tort suit is brought can depend on the attorney's expectation of recovery.

The possibility for recovery in domestic violence tort suits can be quite low. Abusers often have little or no resources to seek through a tort claim. Even if the plaintiff obtains a sizable damages award, the defendant may not have sufficient resources to satisfy the judgment. Plaintiff-side attorneys are reluctant to litigate cases when the chance of receiving a sufficient contingency fee is small. Similarly, the plaintiff may decide that the possible therapeutic, deterrent, or other benefits are not sufficient to warrant filing a claim when the odds of financial recovery are low.

\footnotetext{
265. LAV 2013, supra note 262, at 18.

266. Id. at $10-11$.

267. Id. The LAV Program also specifies that grant funds cannot be used to support legal representation in "[c]hild sexual abuse cases," "[c]ases involving the child protection system," and "[c]riminal defense of victims charged with crimes." Id. Additionally, grant funds cannot be used to support lobbying, fundraising, research projects, or physical renovations of office space. Id.

268. DoBBS, supra note 2, at 38 .

269. Id.

270. Id

271. Id.
} 


\section{Other Concerns}

There are a number of other possible reasons that domestic violence tort cases are rarely filed. A victim may fear retaliation by the abuser, and it may not be safe for her to pursue a tort claim. A victim may prefer to avoid contentious litigation for the sake of tranquility, especially if the abuser is the father of her children. She may have had bad experiences with legal processes before or may not be willing to experience the stress that litigation may cause. The victim may have higher priorities for legal intervention, including cases involving restraining orders, child custody, child support, housing, and public benefits. Lawyers, too, play a limiting role in the development of domestic violence tort jurisprudence. Domestic violence attorneys tend to specialize, almost always in civil restraining order or family law cases. ${ }^{272}$ Even if their funding permits them to do so, these attorneys may feel uncomfortable or unqualified to litigate tort claims. They also may not be advising their clients about tort law as an avenue of relief. If domestic violence victims are not aware of the availability of these claims, they will not pursue them.

There are also procedural issues that can limit the number of domestic violence tort suits. While these procedural complications in domestic violence tort law are beyond the scope of this article, it is worth mentioning the most common of them. Statutes of limitations, which are usually one to six years for intentional torts, operate as a bar to many domestic violence tort claims. ${ }^{273}$ A number of procedural complications can arise if there is or

272. See Camille Carey, Correcting Myopia in Domestic Violence Advocacy: Moving Forward in Lawyering and Law School Clinics, 21 COLUM. J. GENDER \& L. 220, 239 (2011).

273. See Dalton, supra note 66, at 357-63 (discussing the effect of statutes of limitations on domestic violence claims and arguing for a universal tolling provision in domestic abuse cases); Buel, supra note 146, at 1015-18 (arguing for the tolling of statutes of limitations in domestic violence claims under the continuing tort doctrine to prevent abusers from defending on statutes of limitations grounds); Jerry J. Phillips, What is a Good Woman Worth? Tort Compensation for Domestic Violence, 47 LOY. L. REV. 303, 308 (2001) (arguing for the application of the continuing tort doctrine to domestic violence claims to prevent the "roadblock" of statutes of limitaitons); Wriggins, Domestic Violence Torts, supra note 83, at 139-40 (explaining that because of the "complex dynamics of domestic violence," many times when the victim is ready to sue, the statute has already run); Edward S. Snyder, Remedies for Domestic Violence: A Continuing Challenge, $12 \mathrm{~J}$. AM. ACAD. MATRIM. LAW. 335, 360-64 (1994) (arguing that domestic violence should be treated as a continuing tort so that statutes of limitations will not operate as a bar to a victim's recovery); Barbara H. Young, Interspousal Torts and Divorce: Problems, Policies, Procedures, 27 J. FAM. L. 489, 491-93 (1989) (discussing interspousal torts and the statute of limitations, and stating that the "greatest impetus for bringing the tort action before or during the divorce is the running of the statute of limitation on the tort"); Michelle L. Evans, Note, Wrongs Committed During a Marriage: The Child that No Area of the Law Wants to Adopt, 66 WASH. \& LEE L. REV. 465, 481-83 (2009) (discussing approaches to the statute of limitations problem in interspousal tort claims). 
has been a divorce proceeding between the parties. States may require that the tort and divorce cases be joined if the tortious conduct occurred during the marriage, and the abuser may raise res judicata or collateral estoppel as a defense. ${ }^{274}$ Also, boilerplate release clauses in divorce settlements or judgments can prohibit a domestic violence plaintiff from bringing a tort case.

\section{BENEFITS OF TORT SUITS FOR DOMESTIC VIOLENCE PLAINTIFFS: FINANCIAL BENEFITS, THERAPEUTIC BENEFITS, ENHANCEMENT OR REPLACEMENT OF CRIMINAL JUSTICE OUTCOMES, DETERRENCE}

\section{A. Financial Benefits}

Domestic violence victims largely shoulder the cost of the domestic violence to which they are subjected. ${ }^{275}$ They often must bear the cost of medical and mental health treatment that results from an abusive relationship. ${ }^{276}$ Separating from an abuser and establishing a new household

274. See Dalton, supra note 66, at 374-79 (identifying New Jersey as a state that requires divorce and tort claims to be joined, and providing examples of res judicata barring victim's tort claims "on the grounds that the issue of their partners' abuse was fully addressed in the context of the divorce"); Buel, supra note 146, at 1000-07, 1010-14 (discussing joinder and presclusion issues, and noting how "disproportionate division of property" is rarely employed "to provide some measure of compensation for the harmed spouse"); Phillips, supra note 273, at 309 (explaining that if a victim brings a tort suit after a divorce, "a court may find that the divorce is preclusive on the issue of damages," and suggesting that "the best approach may be to try the divorce case first, with open disclosure to the court of a pending or contemplated tort suit," with the fact finder being permitted to consider the divorce award in the tort suit); Scherer, supra note 149, at 567-73 (discussing problems that joinder and preclusion create for domestic violence claims and providing examples of state claims); Richard R. Orsinger, Asserting Claims for Intentionally or Recklessly Causing Severe Emotional Distress in Connection with Divorce, 25 ST. MARY's L.J. 1253, 1295300 (1994) (identifying preclusion problems that may arise when brining an infliction of emotional distress claim after a divorce); Snyder, supra note 273, at 354-60 (discussing joinder and preclusion issues and warning that victims "must be vigilant in joining claims because a failure to do so can result in a res judicata bar to future attempts to gain redress for tortious wrongs"); Young, supra note 273 , at 500-03 (identifying "the greatest risk of the operation of res judicata and equitable estoppel [as] postponing the tort claim," because although pursuing the tort claim first may permit the court to "consider the tort judgment when it divides property and awards maintenance and child support," it cannot "preclude a later divorce"); Evans, supra note 273, at 483-89 (discussing the effects of joining torts and divorce actions, and explaining the tests courts use to determine if an interspousal tort is precluded).

275. Wriggins, Domestic Violence Torts, supra note 83, at 147 ("[C]osts of these domestic violence torts, financial and nonfinancial, are borne largely by the victims. ..."). "Partial estimates show that violent crime against women costs this country at least 3 billion-not million, but billion — dollars a year." U.S. v. Morrison, 529 U.S. 598, 632 (2000) (Souter, J., dissenting) (citing S. REP. No. 101-545, at 33 (1990)).

276. Barbara J. Hart \& Erika A. Sussman, Civil Tort Suits and Economic Justice for Battered Women, VictiM ADVOCATE, Spring 2004, at 3, 4. 
can be very expensive, and victims are usually primarily responsible for financially supporting their children. ${ }^{277}$ Child support and spousal support awards are often insufficient. ${ }^{278}$ Victims also may not receive court-ordered child support or alimony - either because the abuser chooses not to pay or because the abuser has lost his job due to criminal charges or incarceration. ${ }^{279}$ The criminal justice system allows for victim restitution, but "in practice, only a small fraction of expended victims compensation funds go to domestic violence victims." 280 The types of compensation available are narrow, and the amount of restitution can be insufficient. ${ }^{281}$ Additionally, restitution frequently remains uncollectable. ${ }^{282}$

Financial recovery from domestic violence tort cases can not only help victims meet immediate financial needs but also set them up for selfsufficiency and long-term safety. ${ }^{283}$ Tort damages awards may help victims compensate for economic losses sustained during the relationship, such as personal property losses when an abuser has broken or sold the victim's property, income and future earning losses when the abuser has controlled employment or educational opportunities, and debt incurred by the abuser that also binds the victim. ${ }^{284}$ While tort damages awards are not meant to compensate for these specific losses, these awards can be particularly meaningful to domestic violence victims given the economic challenges they face. Abusers almost never bear any financial responsibility for the financial harms caused by their abusive conduct, and tort suits can shift the financial burden from the victim to the abuser through damages awards. ${ }^{285}$

Tort claims offer domestic violence victims the opportunity to receive monetary awards related to the harm they have suffered-including

\footnotetext{
277. Id. at 3-4.

278. Id. at 4 .

279. Id.

280. Wriggins, Domestic Violence Torts, supra note 83, at 147 (citing Desmond S. Greer, A Transatlantic Perspective on the Compensation of Crime Victims in the United States, 85 J. CRIM. L. \& CRIMINOLOGY 333, 348 (1994)). See also Hart \& Sussman, supra note 276, at 4.

281. Hart \& Sussman, supra note 276, at 4.

282. Id.

283. See id. at 8 (instructing that "[i]t is important to view tort litigation as just one among numerous potential legal strategies employed within a larger safety plan," because "the tort attorney can assist in holding the batterer accountable for the violence, while helping the client achieve the economic justice required for her safety and freedom").

284. See, e.g., id. at 4, 6. See generally Angela Littwin, Coerced Debt: The Role of Consumer Credit in Domestic Violence, 100 CALIF. L. REV. 951 (2012) (explaining how abusers coerce their victims into debt, how debt prevents victims from leaving the abusive relationship, and what effects "coerced debt" has).

285. Dalton, supra note 66, at 389-90 (noting that "the abuser never fully pays the bill
} associated with his abuse," and that the tort system could better compensate victims). 
compensatory, nominal, and punitive damages. ${ }^{286}$

\section{Compensatory Damages}

Compensatory damages are available to victims in negligence, recklessness, and intentional tort claims. Compensatory damages include medical expenses and other expenses proximately caused by the injury, lost earnings and lost earning capacity, and pain and suffering. ${ }^{287}$ The damages are generally awarded in a lump sum, accounting for past and future losses that are proximately caused by the injury. ${ }^{288}$ Compensable physical injury is very common in domestic violence relationships. The incidence of physical injury of victims in domestic violence relationships is extremely high. ${ }^{289}$ In one study, $88 \%$ of victims were injured "in the most violent incident" of domestic violence, with $67 \%$ of the victims suffering severe injury. ${ }^{290}$ In addition, $32 \%$ of women had been injured "in the most recent incident" of domestic violence, $5 \%$ severely. ${ }^{291}$

A domestic violence plaintiff is entitled to recover for any pain and suffering proximately caused by the tortious conduct. Recovery for pain includes compensation for pain suffered at the time of or after the liabilitycausing incident and pain from medical treatment of injuries arising from the incident. ${ }^{292}$ Domestic violence also results in compensable mental harm, including fear, anxiety, damaged self-esteem, depression, and post-traumatic stress syndrome. ${ }^{293}$ This harm is awarded as "suffering" in recovery for pain and suffering. ${ }^{294}$ Domestic violence plaintiffs can seek recovery for emotional anguish, distress, or any other negative emotional impact that proximately results from the perpetrator's tortious conduct. ${ }^{295}$ Victims can receive damages for these emotional losses themselves as well as the cost of addressing these losses through psychotherapy and other mental health

286. See Dalton, supra note 66, at 390 ("The award can recognize pain and suffering, as well as the tangible elements, such as medical expenses and lost earnings; punitive damages are also a possibility.").

287. DoBBS, supra note 2, at 1048.

288. Id. at 1047 .

289. See, e.g., JOHNSON, supra note 20 , at 1 (" $25-30$ percent of women who come to emergency rooms for injuries are there for domestic violence-related problems.").

290. Id. at 39, 92-93.

291. Id.

292. DOBBS, supra note 2, at 1050-51.

293. Id. at 41-43.

294. See Dalton, supra note 66, at 390 ("The award [against the abuser] can recognize pain and suffering.").

295. DoBBS, supra note 2, at 1051. 
services, usually framed as medical and related expenses.

\section{Nominal Damages}

Domestic violence plaintiffs can pursue additional damages in intentional tort claims. Nominal damages, which are not available in negligence claims, are available for intentional torts. In negligence, the plaintiff must suffer a legally recognized harm in order to have a cognizable claim. $^{296}$ For intentional torts, such as battery, sexual battery, assault, intentional infliction of emotional distress, and false imprisonment, the legally recognized harm is the tort itself. ${ }^{297}$ For intentional torts, the plaintiff can recover nominal damages and potentially "a substantial [additional] sum without proof of any specific loss other than the tort itself." ${ }^{298}$ For instance, a domestic violence victim who is falsely imprisoned may be entitled to substantial damages even though she was not physically injured, did not suffer from lost wages, and did not introduce evidence of emotional harm. ${ }^{299}$

\section{Punitive Damages}

Domestic violence victims also can seek punitive damages for intentional torts. Punitive damages are permitted in a great majority of states. $^{300}$ Generally, punitive damages require a showing of serious misconduct with a bad intent or state of mind like malice. ${ }^{301}$ Many acts of domestic violence constitute serious misconduct perpetrated by an abuser who is intentionally causing harm. Thus, domestic violence tort claims are ripe for seeking punitive damages awards. Punitive damage awards can be problematic in that jury awards of punitive damages are subject to judicial review and can be reduced or reversed. ${ }^{302}$

Punitive damages awards can be very important in a domestic violence tort suit, however. Abusers commonly prevent victims from working or

\footnotetext{
296. Id. at 1047 (footnote omitted).

297. Id.

298. Id

299. Id. at 80 .

300. Id. at 1062 .

301. Id. at 1064; RESTATEMENT (SECOND) OF TORTS § 908(2) (1979) ("Punitive damages may be awarded for conduct that is outrageous, because of the defendant's evil motive or his reckless indifference to the rights of others. In assessing punitive damages, the trier of fact can properly consider the character of the defendant's act, the nature and extent of the harm to the plaintiff that the defendant caused or intended to cause and the wealth of the defendant.").

302. Phillips, supra note 273, at 310.
} 
seeking an education. ${ }^{303}$ Women statistically earn less than men and tend to occupy the homemaking role more frequently than men. ${ }^{304}$ These financial disadvantages will play out in computation of compensatory damages awards for domestic violence victims, who are largely women. Computation of damages for lost wages and lost earning capacity are based on prior earnings and projected future earnings. ${ }^{305}$ The combination of gender and the financial abuse present in most domestic violence relationships will ultimately reduce compensatory damages awards for lost wages or lost earning capacity for most victims. ${ }^{306}$ Punitive damages awards can help to boost domestic violence victims' recovery to make it more on par with damages awards given to plaintiffs who have not been financially disadvantaged by gender and domestic violence. Punitive damages also carry a punishing sting for the defendant, hopefully creating deterrence of future abusive conduct. Punitive damages may also provide some therapeutic benefits to plaintiffs, as discussed below. ${ }^{307}$ The purposes of punitive damages are to punish the defendant and to deter him from engaging in similar conduct in the future. ${ }^{308}$

\section{Examples of Domestic Violence Tort Damages Awards}

The amount of damages awards in tort cases can vary greatly. ${ }^{309}$ Most domestic violence plaintiffs will not receive enormous damages awards. Modest damages awards are common in the domestic violence tort actions that have been brought. ${ }^{310}$ However, some awards have been in the millions. ${ }^{311}$

\footnotetext{
303. Hart \& Sussman, supra note 276, at 6.

304. Phillips, supra note 273, at 311 (citation omitted).

305. Id.

306. Id.

307. See supra part III.B.

308. RESTATEMENT (SECOND) OF TORTS $§ 908 \mathrm{cmt}$ a a (1979).

309. See 1 THOMSON/WEST, supra note 28 , at 99-107, 111-12, 118-34, 141-43, 143-46 for discussion of domestic violence tort damages awards in specific cases. The majority of damage awards for sexual abuse are between $\$ 60,000$ to $\$ 250,000$ but they can be as high as millions of dollars. ViolenCE AGAinst Women: LAW AND Litigation, supra note 16, § 17:21.

310. See, e.g., Alderson v. Alderson, 225 Cal. Rptr. 610, 612-13 (Cal. Ct. App. 1986) (awarding a plaintiff who cohabited with her boyfriend for twelve years $\$ 15,000$ in compensatory damages and $\$ 4,000$ in punitive damages for assault and battery for injuries sustained when her boyfriend broke her arm); Henriksen v. Cameron, 622 A.2d 1135, 1138, 1144 (Me. 1993) (awarding \$75,000 in compensatory damages and $\$ 40,000$ in punitive damages for intentional infliction of emotional distress).

311. E.g., Results, DONOVAN \& O'CONNOR, LLP, http://www.docattypi.com/Results.shtml (last visited Feb. 8, 2014). In 2006 Chris Dodig obtained a $\$ 9.5$ million judgment in the Berkshire
} 
In one Texas case, O'Keiff $v$. Christ, a domestic violence victim was awarded $\$ 10.9$ million in compensatory damages, $\$ 150$ million in punitive damages, and approximately $\$ 9$ million in court costs and interest. ${ }^{312}$ The husband, who was a plastic surgeon, shot his wife in the face, causing her to lose her left eye and $95 \%$ of her hearing in her right ear. She required thirteen surgeries to repair her shattered eye, nose bones, and frontal sinuses. ${ }^{313}$ In another Texas case, In re Brown, Darlina Brown received a multi-million dollar jury verdict after seeking recovery for domestic violence tort harms as part of her divorce suit. ${ }^{314}$ Brown claimed that her husband Michael Brown, "a prominent surgeon ... beat [her while pregnant] so severely that she went into premature labor." $" 315$ She prevailed on her claims for assault and intentional infliction of emotional distress. ${ }^{316}$ On these claims, the trial court awarded Ms. Brown a judgment of more than \$5.2 million including $\$ 2$ million in punitive damages. ${ }^{317}$

In Massachusetts, Tawnya Underhill received a $\$ 9$ million tort judgment against her former boyfriend, Paul Rathbun. ${ }^{318}$ The Berkshire Superior Court made this award based on one incident of domestic violence. ${ }^{319}$ Rathbun broke Underhill's neck during a domestic violence incident that took place in a car at a resort in Massachusetts. ${ }^{320}$ Underhill was left paralyzed as a result of the incident. ${ }^{321}$

In Curtis v. Firth, the Idaho Supreme Court upheld the trial court's $\$ 1$ million judgment. ${ }^{322}$ In that case, the domestic violence plaintiff received a judgment for $\$ 50,000$ in compensatory damages for battery, $\$ 225,000$ for intentional infliction of emotional distress, and $\$ 725,000$ in punitive

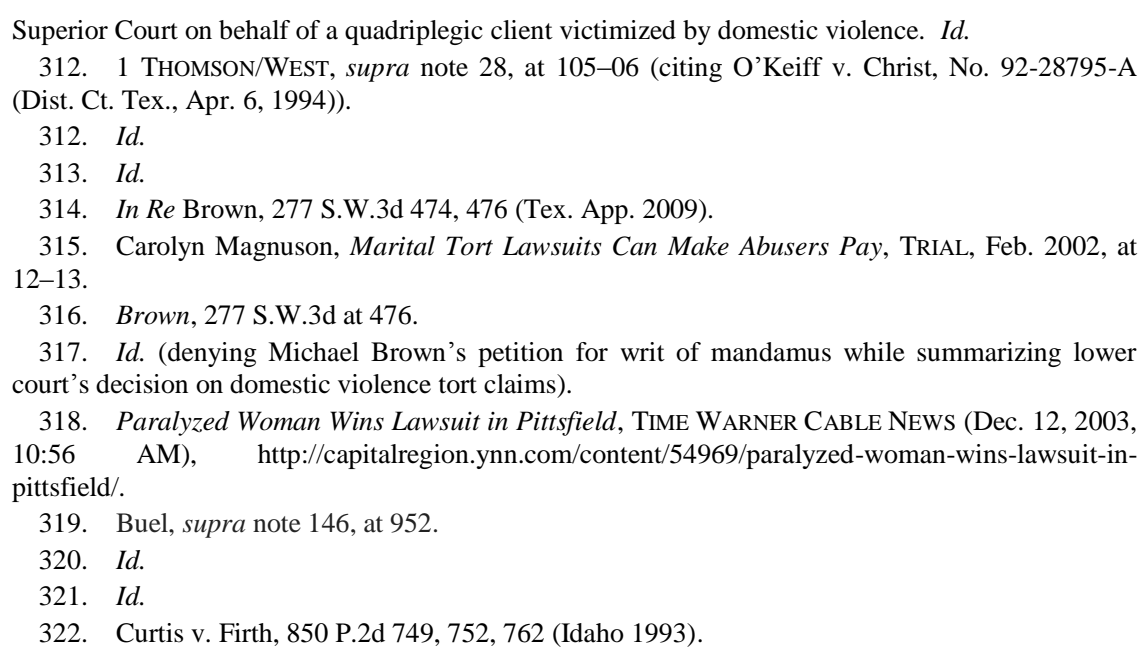


damages. ${ }^{323}$ Carl Curtis and Sandra Firth had been living together in an intimate partner relationship for ten years. ${ }^{324}$ The relationship "was characterized by cycles of violence., 325 Firth testified that Curtis sexually assaulted her, anally raped her, and forced her to engage in sexual acts that she found repugnant. ${ }^{326}$ Still more: Curtis publically screamed at Firth and swore at her; he kicked her out of bed using his foot on her back; he shook her so hard she feared she would fall off a boat dock; he slapped her on the buttocks so hard that it left a hand print; and, he pulled her hair while throwing her against a sink. ${ }^{327}$

Damages awards, large or small, provide financial compensation in an effort to make the plaintiff "whole." Damages offer the plaintiff financial resources for medical and mental health treatment and some financial stability in the face of lost wages. They can also provide monetary recognition of emotional harm and, in some cases, acknowledgment of the egregiousness of the abuser's conduct through punitive damages. This "transfer of a single sum from the defendant to the plaintiff" is intended to be "the remedial embodiment of the correlative nature of doing and suffering harm." 328 Damages awards can never fully right the wrong perpetrated on the plaintiff by her intimate partner. However, as will be discussed below, a domestic violence plaintiff can receive other nonfinancial benefits from pursuing a tort claim against an abuser.

\section{B. Therapeutic Benefits}

Tort actions can provide domestic violence plaintiffs with nonfinancial benefits beyond the financial gain offered by damages awards. Victims may be motivated by the "psychological primacy of compensation" offered by tort suits. ${ }^{329}$ However, financial compensation is not the only benefit that is sought. A plaintiff may choose to file a tort suit in an attempt to meet an emotional need or fulfill a moral imperative. ${ }^{330}$ The literature on therapeutic

\footnotetext{
323. Id. at 752 .

324. Id. at 751 .

325. Id.

326. Id. at 757 .

327. Id.

328. Weinrib, supra note 60, at 513.

329. Daniel W. Shuman, The Psychology of Compensation in Tort Law, 43 U. KAN. L. REV. 39, 48-51 (1994).

330. Edie Greene, "Can We Talk?" Therapeutic Jurisprudence, Restorative Justice and Tort Litigation, in Civil JuRIES AND Civil Justice: PsychologicAl AND Legal Perspectives 233, 234 (Brian H. Bornstein et al. eds., 2008); see Linda K. Meier \& Brian K. Zoeller, Taking Abusers to Court: Civil Remedies for Domestic Violence Victims, TRIAL, June 1995, at 60, 64.
} 
jurisprudence offers some insight into the therapeutic outcomes of tort cases for plaintiffs. Therapeutic jurisprudence examines how legal rules, legal procedures, and the roles of legal actors-including litigants, judges, and lawyers-act as agents in producing therapeutic or anti-therapeutic consequences. $^{331}$ Therapeutic benefits almost certainly occur when a plaintiff is successful in her claim. However, the very act of being a plaintiff in a tort suit has the potential to provide therapeutic benefits.

The therapeutic benefits for plaintiffs in tort suits generally encompass a wide spectrum. A tort claim can help provide closure for a plaintiff. ${ }^{332}$ Pursuing a tort claim can aid in dissipating negative feelings, including relieving the plaintiff's feelings of outrage, resentment, and anger. ${ }^{333}$ The dissipation of these feelings can result from the satisfaction that the defendant has been punished for the harm caused or that the plaintiff has been compensated for the loss suffered. ${ }^{334}$ A court's finding of fault in the defendant can soothe the victim's loss of dignity. ${ }^{335}$ Pursuing a tort claim can also be very empowering for the plaintiff.

The act of being a plaintiff in a tort suit also can aid specifically in the healing process for victims of violence. Victims of violence usually desire redress for the injustice inflicted on them, and the quest for compensation can be an important part of the victim's recovery. ${ }^{336}$ The victim's primary objective is not necessarily seeking financial compensation. Instead, she is likely to be seeking an acknowledgment of harm, an apology, or public humiliation of the perpetrator. ${ }^{337}$

331. David B. Wexler, An Orientation to Therapeutic Jurisprudence, 20 NEW ENG. J. ON CRIM. \& CIV. CONFINEMENT 259, 259 (1994) ("The therapeutic jurisprudence heuristic suggests that the law itself can be seen to function as a kind of therapist or therapeutic agent. Legal rules, legal procedures, and the roles of legal actors . . . constitute social forces that . . . often produce therapeutic or antitherapeutic consequences."); Michael L. Perlin, What is Therapeutic Jurisprudence?, 10 N.Y.L. SCH. J. HUM. RTS. 623, 623-24 (1993).

332. See Shuman, supra note 329, at 50-51 ("[P] unishment of wrongdoers 'tends to relieve the outraged feelings of those who have been hurt; after its infliction their anger abates, and they tend to regard the incident as closed."').

333. Id.

334. See id. at 51 ("The resentment of the victim and of society can be appeased by punishment (the criminal sanction) or satisfied by reparation (the civil sanction).").

335. See id. at 50 ("[T]here is ample contemporary evidence to suggest that tort damages may play a powerful role in the restorative process.").

336. Judith LEWIS HERMAN, TRAUMA AND RECOVERY 190 (1992).

337. Id. Herman discusses the value of compensation in a victim's recovery but also notes the hurdle that a victim's attachment to compensation can provide. Id. "The quest for fair compensation ... also presents a potential trap. Prolonged, fruitless struggles to wrest compensation from the perpetrator or from others may represent a defense against facing the full reality of what was lost.... Though the fantasy is about empowerment, in reality the struggle for compensation ties the patient's fate to that of the perpetrator and holds her recovery hostage to his whims. 
Involving the civil judicial system can offer the plaintiff acknowledgment of and validation for the wrongness of the harms suffered. Tort suits provide litigants with an opportunity to articulate their harms and have their experiences validated. Plaintiffs file tort claims "as a way to be heard and to have their claims dignified by a court of law." 338 For a domestic violence victim, the opportunity to tell a judge or a jury about the abuse she has endured can be very powerful. Establishing that the plaintiff's "case is worthy of judicial attention may provide satisfaction and validation to some plaintiffs." 339 A verdict for the plaintiff can be extremely therapeutic.

Tort claims also give domestic violence victims an opportunity to exert power in an otherwise subordinating relationship. In general, the availability of compensation through the tort system allows tort litigants to enlist the "coercive power of the judicial system to reshape the power imbalance in their relationships." 340

There is insufficient data concerning the therapeutic effects of participation in tort litigation on parties. ${ }^{341}$ Similarly, therapeutic jurisprudence has not yet comprehensively addressed the extent to which successful outcomes of tort cases assist in a plaintiff's restoration. ${ }^{342}$

One article published in Canada examined the therapeutic benefits for victims of sexual assault who were plaintiffs in tort suits. ${ }^{343}$ Bruce Feldthusen analyzed the therapeutic jurisprudence implications for plaintiffs in thirty-three sexual battery tort cases filed in Canada. ${ }^{344} \mathrm{He}$ found that many of these plaintiffs reported therapeutic, nonfinancial motivations for

\footnotetext{
Paradoxically, the patient may liberate herself from the perpetrator when she renounces the hope of getting any compensation from him." Id.

338. Greene, supra note 330, at 235.

339. Id.

340. Shuman, supra note 329, at 56. In studying the Mexican Zapotec courts, and the use of such courts to reshape personal relationships, Laura Nader noted that "[t]he Zapotec ideal is not an 'eye for an eye,' but rather what restores personal relations to equilibrium." LAURA NADER, STYLES of Court Procedure: To MaKe the Balance, in LaW and Culture in Society 73 (Laura Nader ed., 1969); PAtrick AtiYAh, ACCIDENTS, Compensation AND the LaW 471, 553 (3d ed. 1980). ("When a person is involved in a dispute with another who he thinks has done wrong, and when that other refuses to admit that he has done wrong (and sometimes even when he does admit it), it may be a great satisfaction to the former to know that he has the right to summon the latter before one of Her Majesty's judges for a public confrontation in which the latter may be branded as in the wrong.").

341. Greene, supra note 330, at 235-36.

342. Shuman, supra note 329 , at 50.

343. Bruce Feldthusen, The Civil Action for Sexual Battery: Therapeutic Jurisprudence?, 25 OTTAWA L. REV. 203 (1993).

344. Id. at 206 n.5.
} 
suing. ${ }^{345}$ The plaintiffs' therapeutic motivations for filing a tort claim included furthering the healing process, punishing the defendant, publicly vindicating the wrong, and encouraging other victims. ${ }^{346}$

Feldthusen found that the prospect of financial compensation for a plaintiff who has been the victim of sexual assault often is not the driving motivator in filing a tort claim. ${ }^{347}$ He noted that plaintiffs who file tort claims for sexual battery often file and litigate these claims even if they know in advance that there would be almost no prospect of collecting a judgment. ${ }^{348}$ The ability to pursue a tort claim for these victims instead offers them other nonfinancial benefits. ${ }^{349}$

A study of the therapeutic benefits for domestic violence plaintiffs has yet to be conducted. In the absence of empirical evidence concerning the therapeutic benefits of tort litigation for plaintiffs in general, it is difficult to determine whether the therapeutic benefits outweigh the counter-therapeutic benefits. It is possible that the counter-therapeutic impact of litigating a tort claim outweighs the positive consequences both for plaintiffs in general and domestic violence plaintiffs in particular. Litigation can be a traumatic process, and the continuing contentiousness of the case and attendant stress can outweigh the benefits of pursuing the litigation. ${ }^{350}$ The litigation process itself can halt or delay the plaintiff's process of healing and restoration. ${ }^{351}$ Litigation often has health and mental-health costs for parties-sometimes leading to lingering medical and psychological issues. ${ }^{352}$ It is also time intensive, taking away from the plaintiff's time for work, family, and recreation. ${ }^{353}$ The victim may have negative experiences within the

\footnotetext{
345. Id. at 211

346. Id. at $211-12$.

347. Id. at 210 .

348. Id.

349. While beyond the scope of this paper and not immediately related to domestic violence, it is important to note that the body of research on victim participation in truth and reconciliation commissions has been inconclusive on whether victim testimony has therapeutic value for the victim. See, e.g., Debra Kaminer et al., The Truth and Reconciliation Commission in South Africa: Relation to Psychiatric Status and Forgiveness Among Survivors of Human Rights Abuses, 178.4 THE BRIT. J. OF PSYCHIATRY 373 (2001) (finding that giving public or closed testimony to the truth commission produced neither a notable therapeutic effect nor a notable counter-therapeutic effect and that some individuals may have experienced testifying as either distressing or relieving); MARY E. Hawkesworth, Globalization \& Feminist Activism (2006) (providing an overview of victim testimony in tribunals on crimes against women that emulate war crime tribunals without any specific discussion of the therapeutic benefits of such testimony).

350. Greene, supra note 330, at 233.

351. Id

352. Id. at $239-41$.

353. Id. at 239 .
} 
historically male-biased legal system, and the abuser might file frivolous motions or claims or exploit opportunities to call the plaintiff back into court in an effort to assert dominance or create fear. ${ }^{354}$ A tort suit may also fail to satisfy the plaintiff's need to be compensated by the defendant when a third party-such as an insurance company-provides the payment to the plaintiff. $^{355}$

Each victim needs to make an individualized decision about whether the potential benefits of tort litigation outweigh the possible drawbacks. For some victims, the factors will weigh in favor of pursuing a tort suit. In addition to the therapeutic benefits discussed above, there are supplemental benefits that arise out of using the tort system rather than the criminal justice system to address domestic violence harms.

\section{Enhancement or Replacement of Criminal Justice Outcomes}

Domestic violence tort suits offer many of the positive outcomes available in criminal cases, but give the victim much greater control. In fact, with criminal cases, the victim is often not even a party. Domestic violence tort suits, on the other hand, offer a victim the opportunity not only to be a party, but also to control the litigation to a large degree. Many of the potential outcomes offered by criminal cases-deterrence, punishment, accountability, and retribution - are also available through civil tort claims, but with the added benefit of the victim being at the helm.

\section{Primacy of the Victim}

In criminal domestic violence cases, the government sues the perpetrator for acts committed against the victim. The victim's interests are "considered relevant in the criminal justice system only to the extent that they coincide with the government's interest in bringing the perpetrator to justice." 356 The police decide whether to arrest, and the prosecutor decides whether to

354. See Susan L. Miller \& Nicole L. Smolter, "Paper Abuse": When All Else Fails, Batterers Use Procedural Stalking, 17.5 VIOLENCE AGAINST WOMEN 637 (2011) (exploring "[t]he barrage of men's frivolous lawsuits, false reports of child abuse, and other system-related manipulations," which "exert . . . power, force . . . contact, and financially burden . . . their ex-partners"); Mary Przekop, One More Battleground: Domestic Violence, Child Custody, and the Batterers' Relentless Pursuit of Their Victims through the Courts, 9 SEATTLE J. Soc. JuST. 1053 (2011) (examining "the unfortunate prevalence and often unpunished abusive behavior perpetrated by batterers in our family courts").

355. Greene, supra note 330 , at 240.

356. Shuman, supra note 329, at 72 (citing Juan Cardenas, The Crime Victim in the Prosecutorial Process, 9 HARV. J.L. \& PUB. POL'Y 357 (1986)). 
prosecute. The victim is almost never consulted about whether a criminal case is filed, how it will proceed, and what outcomes will be sought. This is especially true in jurisdictions that follow mandatory arrest and mandatory prosecution policies. In fact, interactions with the police and the criminal justice system can have anti-therapeutic effects for domestic violence victims. ${ }^{357}$

Domestic violence plaintiffs, as opposed to the state, can determine the course of the case in pursuing justice through tort claims. As the potential plaintiff in a tort suit, the victim exercises significant power. To start, the victim chooses whether to initiate a suit. If she does file suit, the victim decides the legal theory for her case, and, except as limited by the power of the court and influence of the other party, what evidence she will presentincluding factual evidence and expert testimony. ${ }^{358}$ She decides when to file - so long as it is within the statute of limitations - and has the power to settle or withdraw the claim at any point. Tort cases also offer victims the chance to define the harm suffered in the way in which they experienced it. ${ }^{359}$

Pursuing remedies through civil as opposed to criminal courts can offer additional therapeutic benefits to plaintiffs. The control offered by a civil suit gives the plaintiff much more satisfaction with the judicial process. Studies have shown that when an individual is a more active participant in litigation and perceives that she has more control over the legal process and outcome, the process is more satisfying to that individual ${ }^{360}$ and seems fairer. ${ }^{361}$ Also, when individuals experience more control in litigation, they are more likely to feel that justice has been served. ${ }^{362}$ Victims particularly prefer a process in which they can participate, have a voice, and have some control. ${ }^{363}$ There is also some support for the idea that "by seizing control of the litigation, by speaking out, and bringing the perpetrator to justice," the victim "can restore her self-control and self-respect." 364 In the domestic

357. See Leonore M.J. Simon, A Therapeutic Jurisprudence Approach to the Legal Processing of Domestic Violence Cases, 1 Psychol. PuB. POL'Y \& L. 43, 62-71 (1995).

358. Feldthusen, supra note 343 , at 216.

359. Id.

360. E. Allan Lind et al., In the Eye of the Beholder: Tort Litigants' Evaluations of Their Experiences in the Civil Justice System, 24 LAW \& SOC'Y REV. 953, 959-60 (1990) (arguing in favor of formal process but warning that alternate dispute resolution may be more therapeutic than trial for some litigants).

361. Id. at 958 .

362. Id. at 973 .

363. Feldthusen, supra note 343, at 217.

364. Id. at 216 . 
violence context, when victims have control over the tort suit that they would not have in the criminal process, they are more likely to feel satisfied with the legal process, believe that the system is fair, and experience justice.

\section{Standard of Proof}

Tort suits also have a better chance of providing the victim with a favorable outcome, given the different standards of proof in civil and criminal cases. In civil cases, the standard of proof is the preponderance of the evidence, while in criminal cases the standard of proof is the much higher "beyond a reasonable doubt." Because the standard of proof for a tort action is significantly lower, the plaintiff may be more likely to succeed in imposing legal accountability, deterrence, and retribution for the defendant's actions. In the domestic violence context, a tort plaintiff will have a lower standard of proof in a civil court for proving the same or similar incidents of abuse. If there has been a criminal conviction, the plaintiff may be able use that conviction to support issue preclusion or a motion for summary judgment related to the underlying act or acts in the tort case. ${ }^{365}$

\section{Power Dynamics}

The civil system is also more likely than the criminal system to create an adjustment in the power dynamic between the victim and the abuser. The criminal justice system is unlikely to address or correct the power imbalance between the victim and the perpetrator. ${ }^{366}$ In fact, the criminal system may recreate a power imbalance, with the criminal system and its players asserting dominance over the victim. ${ }^{367}$ Giving the victim legal power through the civil system is "empowerment per se" and holds particular significance in situations of power and control by an abuser. ${ }^{368}$

[T] he victim's decision to file and maintain a lawsuit may be a source of a cognitive shift.... Therefore, returning the initiative to the victim may help redefine her sense of self as empowered. Filing a claim allows the plaintiff to regain control over her life; she changes from a

\footnotetext{
365. Betty Levinson, Domestic Violence and Tort Remedies, in LAWYER's MANUAL ON Domestic Violence: Representing the Victim 247, 254 (Ronald E. Cohen \& James C. Neely eds., 2d ed. 1998); Kathleen L. Daerr-Bannon, Causes of Action in Tort for Spousal Abuse, 41 CAuses of ACTION 2d, at $407 \S 4$ (2009).

366. Feldthusen, supra note 343, at 214-15.

367. Id.

368. Ronen Perry, Empowerment and Tort Law, 76 TENN. L. REV. 959, 975 (2009).
} 
helpless victim to an active vindicator of her rights and interests. ${ }^{369}$

By filing a tort claim, the victim rejects the abuser's "claim of superiority and reasserts her autonomy.",370

\section{Civil Claims in Lieu of Prosecution}

The availability of tort remedies to domestic violence victims can be particularly significant when the state declines to investigate or prosecute. This is especially true given the low prosecution rate of domestic violence crimes. Statistics on domestic violence reporting, arrest, prosecution, and incarceration rates vary greatly depending on the study and the location of the study. Most statistics reveal that individual victims rarely can rely on the criminal justice system to punish, deter, or control an abuser.

One Department of Justice (DOJ) study found that in instances of physical assaults of women by an intimate partner, only $7.3 \%$ of the perpetrators were prosecuted. ${ }^{371}$ Of that number, $47.9 \%$ were convicted, and of those convicted, $35.6 \%$ were sentenced to jail or prison. ${ }^{372}$ In cases of intimate partner rape, only $7.5 \%$ of the perpetrators were prosecuted; of that number, $41.9 \%$ were convicted, and of those convicted, $69.2 \%$ were sentenced to jail or prison. ${ }^{373}$ In another study funded by the DOJ and based on 135 studies, researchers determined that of reported domestic violence offenses, $35.5 \%$ were prosecuted, while $57.6 \%$ of domestic arrests were prosecuted. ${ }^{374}$ A well-publicized study in Milwaukee found that $95 \%$ of men arrested for domestic violence were not prosecuted, and of those prosecuted, only $1 \%$ of those prosecuted were convicted. ${ }^{375}$

A DOJ Special Report found that of perpetrators who were charged with

369. Id

370. Id. at $975-76$.

371. Patricia Tuaden \& Nancy Thoennes, U.S. Dep't of Justice, Nat'L Inst. of Justice, NCJ 181867.9, EXTENT, NATURe, AND CONSEQUENCES OF INTIMATE PARTNER Violence: Findings From the NAtional Violence Against Women SuRvey 51 (2000), available at https://www.ncjrs.gov/pdffiles1/nij/181867.pdf.

372. Id.

373. Id.

374. Joel H. Garner \& Christopher D. MAXwell, U.S. Dep'T of Justice, Nat'L InST. OF Justice, NCJ 236959, The Crime Control EFFeCts of Criminal SANCtions for Intimate PARTNER VIOLENCE 97 (Sept. 30, 2010), available at https://www.ncjrs.gov/pdffiles1/nij/grants/236959.pdf.

375. Joan Zorza, The Criminal Law of Misdemeanor Domestic Violence, 1970-1990, 83 J. CRIM. L. \& CRIminology 46, 71 (1992) (citing Lawrence W. Sherman et al., From Initial Deterrence to Long-Term Escalation: Short Custody Arrest for Poverty Ghetto Domestic Violence, 29 CRIMINOLOGY 821 (1991)). 
a domestic violence crime, $81.5 \%$ were charged with only a misdemeanor, and about $18.5 \%$ were charged with a felony. ${ }^{376}$ The same report found that more than half of these charged defendants were convicted, and that of those convicted, more than $80 \%$ of the defendants received jail or prison time, with the remaining convicted defendants receiving probation. ${ }^{377}$ A survey of multiple studies of domestic violence criminal justice outcomes revealed that the percentage of perpetrators receiving jail sentences ranged from no more than $4 \%$ (in four of the studies) to $57 \%$ (in Brooklyn). ${ }^{378}$

While the rates of arrest, prosecution, and incarceration vary, each study indicates percentages in which there are no outcomes whatsoever in the criminal case. For instance, in the first-referenced DOJ study, if only $7.3 \%$ of perpetrators of intimate partner assault on women are prosecuted, $92.7 \%$ of perpetrators are not being prosecuted and the criminal justice system has not achieved an outcome for the victim. This enormous gap indicates that the criminal justice system is not adequately serving victims and that other viable options, including remedies in tort, are needed.

\section{Tort Claims when Victim Avoids the Criminal Process}

Tort claims are also a useful alternative when a victim prefers that the state not prosecute and the victim does not file a complaint, press charges, or participate in the prosecution. There are a number of valid reasons why a victim may choose not to mobilize the criminal justice system. The victim may not want the perpetrator to be incarcerated out of concern for the perpetrator or his children. ${ }^{379}$ The victim may eschew the involvement of the criminal system for financial reasons. The victim and perhaps her children may be dependent on the perpetrator for financial support, including for housing, food, payment of household bills, child support, or alimony. ${ }^{380}$ Additionally, the victim may know that the threat of criminal sanctions will not deter her particular abuser.

Domestic violence torts can be a good option for victims given that a

376. ERica L. Smith \& Donald J. Farole, JR., U.S. Dep’tT of Justice, Bureau of Justice Statistics, NCJ 228193, Profile of Intimate Partner Violence Cases in Large Urban COUNTIES 2 (Oct. 2009), available at http://www.bjs.gov/content/pub/pdf/pipvcluc.pdf (stating that, of the 3,750 domestic violence charges in the study, only 693 were felonies and the remaining 3,057 were misdemeanors).

377. Id. at 6 . The study was based on intimate partner violence cases. Id. at 1 . These cases made up $83 \%$ of the domestic violence cases filed in the 16 counties. Id.

378. GARNER \& MAXWELL, supra note 374, at 75 tbl.3-3.

379. Feldthusen, supra note 343, at 227.

380. Id. 
high percentage of domestic violence criminal cases are dropped. Statistics on dropped prosecutions vary. In one study of cases filed in Chicago's domestic violence court, 7,400 of 10,700 - or $69 \%$ of - cases had been dropped. ${ }^{381}$ In another study in Detroit, only $2.6 \%$ of domestic assault cases brought to the attention of law enforcement resulted in adjudication. ${ }^{382}$ Victim noncooperation plays a role in the high rates of prosecution failure. Some studies have shown that 78 to $85 \%$ of victims decline to participate in prosecution. $^{383}$

These high rates of noncooperation signify that the criminal justice system is not effective in meeting victims' needs. Tort remedies will not suit all victims either. However, tort law does provide an important option given the problems presented by the criminal system.

Many reasons that victims choose not to participate in prosecuting their abusers relate specifically to the criminal justice system. Victims have cited the following as reasons not to cooperate: prior negative experiences with the criminal justice system, frustration with the process, having insufficient information about how the system works, concern with prosecution's effect on children, emotional barriers such as love for the abuser and fear of retaliation, and lack of resources required to participate, such as time, money, emotional support, and transportation. ${ }^{384}$ Victims also have faced barriers such as getting the police to provide assistance and having the system follow through with charges. ${ }^{385}$ Some victims fear that invoking the

381. Deborah Nelson \& Rebecca Carr, Some Frustrated Victims Talk of Taking Up Arms, CHI. Sun-TiMES, July 24, 1994, at 18, available at http://www.highbeam.com/doc/1P2-4239618.html.

382. Maureen McLeod, Note, Victim Noncooperation in the Prosecution of Domestic Assault, 21 CRIMINOLOGY 395, 408 (1983).

383. ERica L. Smith et al., U.S. Dep't of Justice, Bureau of Justice Statistics, NCJ 214993, State Court Processing of Domestic Violence Cases 2 (2008), available at http://www.bjs.gov/index.cfm?ty=pbdetail\&iid=1201 (finding that "of domestic sexual and aggravated assault cases not prosecuted, $78 \%$ were dismissed or declined for prosecution because victims would not cooperate"); Alafair S. Burke, Domestic Violence as a Crime of Pattern and Intent: An Alternative Reconceptualization, 75 GEO. WASH. L. REV. 552, 576 (2007) (summarizing that researchers estimate that approximately $80 \%$ or more of domestic violence victims decline to cooperate as complaining witnesses in the criminal prosecutions against their abusers, while only 10 to $20 \%$ choose to participate); Tom Lininger, Prosecuting Batterers After Crawford, 91 VA. L. REV. 747, 768-69 (2005) (summarizing research that suggests that 80 to $85 \%$ of victims will recant at some point). But cf. Anat Maytal, Specialized Domestic Violence Courts: Are they Worth the Trouble in Massachusetts?, 18 B.U. PUB. INT. L.J. 197, 205 (2008) (citing studies that found that "with the help of victim assistance programs, only ten percent of domestic assault victims in Los Angeles refused to cooperate with the prosecutor, and in Santa Barbara, only eight percent refused to cooperate").

384. Karin V. Rhodes et al., Nat'l InSt. of Justice, Victim Participation in InTimate PARTNER VIOLENCE PROSECUTION: IMPLICATIONS FOR SAFETY 48 (2011).

385. Id. at 51 . 
criminal justice system could lead to involvement of child protective services and possible removal of children from the home. ${ }^{386}$ Others correctly perceive that prosecution or incarceration will affect the victim's ability to receive financial support from the abuser. ${ }^{387}$ A victim might choose to opt out of the criminal justice system because the process is too complicated, emotionally draining, burdensome, and "not worth the hassle." 388 However, a victim's failure to participate does not necessarily mean that she is opposed to the prosecution of her abuser. Barriers alone can be enough to thwart her participation. ${ }^{389}$

Some of the barriers to participation in the criminal justice system may also dissuade victims from filing tort claims. Victims may fear retaliation, including further violence, ${ }^{390}$ or withdrawal of financial support. ${ }^{391}$ Others may believe that abuse is a private or domestic matter. ${ }^{392}$ Love or affection for the batterer or hope for the relationship can also affect a victim's decisions about whether to engage the legal system. These factors may weigh against filing a domestic violence tort claim for some victims. However, many of the barriers to participating in the criminal justice system will not stand in the way of filing a tort case. The victim may have no experience with the tort system, as opposed to a history of negative experiences with the criminal justice system. Instead of risking losing financial support if the abuser were to be prosecuted or incarcerated, the victim may receive a substantial tort award, providing both immediate and future financial support.

\section{Deterrence}

Domestic violence torts offer the potential to deter abusers from engaging in abusive conduct. As discussed above, the criminal justice system - with its low rates of prosecution, arrest, and victim participationoften fails to deter domestic violence. Additionally, some domestic violence

\footnotetext{
386. Id. at 25-26, 47; Lininger, supra note 383 , at 751.

387. Lininger, supra note 383 , at 769.

388. RHODES ET AL., supra note 384, at 18.

389. Id.

390. Andrew R. Klein, U.S. Dep’t of Justice, NCJ 225722, NAt’L Inst. of Justice, PRACTICAL IMPLiCATIONS OF CURRENT DOMESTIC VIOLENCE RESEARCH: For LAW ENFORCEMENT, PROSECUTORS AND JUDGES 11, 46 (2009), available at https://www.ncjrs.gov/pdffiles1/nij/225722.pdf; Lininger, supra note 383, at 769; RHODES et al., supra note 384 , at 18 .

391. Lininger, supra note 383, at 769-70.

392. KLEIN, supra note 390, at 5; McLeod, supra note 382, at 400.
} 
perpetrators are not swayed by the threat of criminal sanctions, including arrest or possible incarceration. Financial sanctions obtained through tort claims, however, can supplement or replace the deterrent effect of the criminal justice system.

Deterrence is a foundational goal of tort law. In the tort context, deterrence seeks to discourage certain conduct by imposing civil liability when the conduct causes harm. ${ }^{393}$ The aim of this deterrence generally is to discourage the public from engaging in certain conduct in order to avoid potential liability - as opposed to holding a party liable for tortious conduct to deter future such conduct. ${ }^{394}$ At least for now, the latter form of deterrence is more applicable in the domestic violence context. Because so few domestic violence tort suits are filed, it is extremely unlikely that an abuser would be aware of this potential civil liability and alter his conduct to avoid it. Until domestic violence tort law is well developed and well known, domestic violence torts will do little to deter abusive conduct before a lawsuit is filed. One would hope that once domestic violence tort law becomes more established and well known, it will reduce abuse against intimate partners.

Domestic violence torts also have the potential to deter subsequent abuse by holding perpetrators civilly liable for prior abusive conduct. The abuser's abusive acts will no longer be "private" after pleadings are filed and evidence of the abuse is presented. A judge and possibly a jury will scrutinize the defendant's behavior. The court's commitment of time and attention to the harms inflicted will emphasize the severity and wrongfulness of the abuser's choices. All of the above aspects of accountability occur even in the absence of a favorable decision for the plaintiff. ${ }^{395}$ In addition, the plaintiff's initiative in filing a tort claim may reduce the risk of future abuse. $^{396}$

If the domestic violence plaintiff prevails, the tort suit can offer even greater deterrence. Payment of damages to the plaintiff will be a meaningful and negative consequence for the abuser's behavior. The defendant may experience payment of compensatory damages, meant to make the plaintiff "whole," as punishment or retribution. If punitive damages are awarded, the defendant is being explicitly punished for his conduct. In addition, a judgment with a finding of liability for the defendant can make the

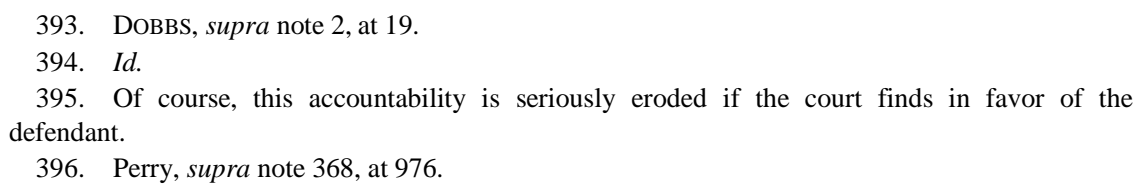


defendant feel "blamed, condemned, and humiliated." ${ }^{397}$ This result can help to deter subsequent domestic violence.

I had the opportunity to witness the deterrent value of a domestic violence tort case firsthand in Gyerko v. Gyerko. ${ }^{398}$ This case was litigated while I was co-supervising the Domestic Violence Clinic at Yale Law School with Robert Solomon. ${ }^{399}$ The parties, who were both natives of Romania, had divorced after a violent and traumatic thirty-three year marriage. Throughout the marriage, the defendant continuously subjected the plaintiff to extreme physical, emotional, and sexual abuse. During the two-year pendency of the divorce action, the defendant continued to threaten and stalk the plaintiff. The defendant disregarded numerous civil restraining orders and criminal protective orders. At one point during the pendency of the divorce action, the police installed a video camera in the plaintiff's bedroom to dissuade the defendant from breaking into the plaintiff's house. The defendant broke into the house and destroyed the video camera. Civil restraining orders, criminal protective orders, arrest, prosecution, and incarceration did not deter the defendant. We represented the plaintiff in filing a complaint alleging intentional infliction of emotional distress, negligent infliction of emotional distress, invasion of privacy, and stalking. The complaint requested an amount equal to the defendant's interest in the marital property, or $\$ 54,100 .{ }^{400}$ The facts of the case could have supported many other counts, including assault and battery, but the statute of limitations had run on those claims. After a trial and a judgment for the plaintiff in the amount of $\$ 54,100$, the defendant finally stopped his abusive behavior.

\section{SHORTCOMINGS OF DOMESTIC VIOLENCE TORTS}

While tort law provides many positive outcomes for domestic violence victims, its causes of action fail to capture some important aspects of domestic violence. When an abuser perpetrates domestic violence, he intends not only to cause the immediate, intended harm, but also to establish power and control over the victim. While tort actions can grant recovery for the emotional and physical harm of the immediate act of violence, they are not well suited to provide recovery for the harm caused by the control

\footnotetext{
397. Lind et al., supra note 360 , at 956.

398. No. NNH-CV09-5025827-S, 2009 WL 2357968 (Conn. Super. Ct. 2009).

399. For more information about the Yale Law School Domestic Violence Clinic, see Carey, supra note 272.

400. Gyerko, 2009 WL 2357968 , at $* 3$.
} 
exerted over the victim by the abuser.

Domestic violence is a pattern of coercive control that constitutes an "institution of confinement." ${ }^{401}$ Domestic violence "involves a pattern of coercive control that is often much more debilitating than the violence itself." ${ }^{, 402}$ Coercive control is a

course of calculated, malevolent conduct deployed almost exclusively by men to dominate individual women by interweaving repeated physical abuse with three equally important tactics: intimidation, isolation, and control. Assault is an essential part of this strategy and is often injurious and sometimes fatal. But the primary harm abusive men inflict is political, not physical, and reflects the deprivation of rights and resources that are critical to personhood and citizenship.

Domestic violence can be seen as a "liberty crime' ... in which the victim is deprived of basic freedoms in her personal life." "404 The loss of liberty inherent in the coercive control of domestic violence is a serious harm that is not easily quantifiable and cannot be addressed by existing common law tort claims. This non-compensable harm is serious, causing victims to "feel like prisoners as they go about the rounds of daily existence." 405

Tort law may also fall short in addressing the effects of minor violence. Domestic violence is frequently defined by instances of severe violence, but often a victim's most significant harm results from the effects of frequent and recurrent low-level violence inflicted on her as part of the abuser's efforts to maintain control. ${ }^{406}$ While this low-level violence is actionable, plaintiffs may have more difficulty obtaining judicial recognition of these harms as opposed to more serious violence.

Recovery for the harm caused by psychological abuse also may be difficult to seek in tort. Psychological abuse, which can be particularly harmful in the context of physical and sexual abuse, may not be compensable outside the strict standards of IIED. Psychological abuse encompasses a wide range of conduct intended to maintain domination over the victim. ${ }^{407}$ Domestic violence perpetrators frequently verbally abuse their

\footnotetext{
401. STARK, supra note 12, at 199.

402. JOHNSON, supra note 20, at 46.

403. STARK, supra note 12 , at 5 .

404. JoHnson, supra note 20, at 46-47.

405. STARK, supra note 12, at 199.

406. Id. at 242-43.

407. DutTon, supra note 23, at 25-27.
} 
partners, including demeaning them with name-calling and degrading comments. ${ }^{408}$ The perpetrator will focus on the partner's vulnerabilities and attack her value as an individual or as a mother, homemaker, family member, friend, employee, or member of the community. ${ }^{409}$ A perpetrator also may force a partner to engage in degrading conduct, like getting on her knees and using a toothbrush to clean up food smeared on the floor by the perpetrator or forcing her to pick up her children from a mistress's home. ${ }^{410}$ To control the victim, abusers sometimes threaten to take away, kidnap, or physically or emotionally abuse the victim's children. ${ }^{411}$ This kind of emotional abuse, which causes serious harm to the victim, has no clear correlate for compensation in tort law.

Tort claims generally do not compensate victims for losses that result from financial abuse. Many domestic violence perpetrators use economic tools to further control and dominate their partners. ${ }^{412}$ Abusers create economic dependency and deprive victims of financial resources by restricting the victim's ability to obtain or maintain employment or seek education. ${ }^{413}$ In one study, $46 \%$ of domestic violence victims reported that their abusers had forbidden them to work, and $25 \%$ reported that their abusers prevented them from attending school. ${ }^{414}$ Abusers often use financial control to trap the victim in the relationship. ${ }^{415}$ They frequently maintain complete control over financial resources - including money-and the food, transportation, shelter, clothing, and other basic necessities it provides. ${ }^{416}$ Abusers also often deprive victims of funds for basic needs or keep them on a strict allowance, providing minimal funds on an as-needed basis. ${ }^{417}$ Abusers often restrict or deny the victim access to financial resources, including the abuser's employment income, family funds, and the victim's income from her own employment. These economic losses suffered

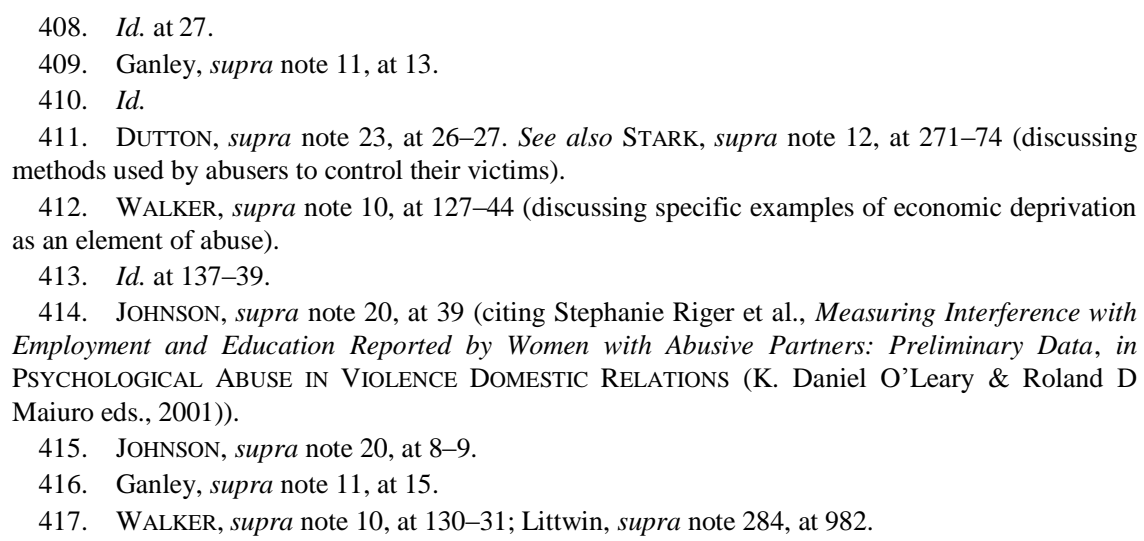


by the victim generally cannot be recouped through existing tort remedies. Tort law would need to be expanded to compensate victims for these losses, as well as lost or deferred educational or employment opportunities. ${ }^{418}$

Tort claims also do not compensate for "social battering." Social battering is the social isolation and humiliation that is frequently imposed on victims by their abusers. ${ }^{419}$ Abusers generally seek to control an intimate partner's attention, time, activities, and relationships with friends and family. ${ }^{420}$ They intentionally isolate the victim and attempt to control her time through accusations of spending too much time with family members, children, friends, and others. ${ }^{421}$ The abuser may prohibit his partner from socializing. He may refuse to accompany her to social events or, if he does accompany her, may humiliate her publicly. ${ }^{422}$ These domestic violence harms do not have ready remedies in common law torts or even in specific domestic violence torts or gender-motivated violence suits.

\section{PARADIGM SHIFT IN DOMESTIC VIOLENCE: LAWYERING TOWARD DOMESTIC VIOLENCE TORTS}

Despite its limitations, tort law offers numerous, largely untapped benefits to prospective domestic violence plaintiffs. An increased focus on domestic violence tort law is an important step in a much-needed paradigm shift in domestic violence lawyering. Criminal justice policies have become the primary strategy for addressing domestic violence. ${ }^{423}$ Currently, civil domestic violence lawyering focuses almost exclusively on restraining orders and family law cases - including child custody, child support, divorce, spousal support, and paternity matters. Legal representation in these cases is undoubtedly vital. However, this narrow approach fails domestic violence victims on many levels. It prioritizes short-term safety, care of children, and legally terminating the relationship over other values like financial compensation, long-term financial security, victim empowerment, deterrence, and abuser accountability. It also neglects the other legal needs of victims - including assistance with housing, public benefits, employment, immigration, consumer, and other matters. A

\footnotetext{
418. STARK, supra note 12 , at 381.

419. WALKER, supra note 10, at 165-84 (discussing specific examples of social battering).

420. Ganley, supra note 11, at 14 .

421. Id.

422. WALKER, supra note 10, at 170-73.

423. Deborah M. Weissman, The Personal is Political — and Economic: Rethinking Domestic Violence, 2007 BYU L. REV. 387, 402 (2007).
} 
continued focus on civil restraining orders and family law diverts attention away from other productive avenues for relief, especially tort law. Tort claims need to comprise a much larger percentage of legal actions brought to address domestic violence.

Employing tort law to address domestic violence harms is an important step in the development of legal doctrine that reflects sex equality in its handling of violence. Filing tort claims for domestic violence will bring intimate partner violence out of family courts. Family courts are often seen as forums for "private" matters. Domestic violence tort claims are heard in general civil courts, giving these claims the same level of importance as other claims between strangers or non-intimate parties.

Offering a dignified forum for domestic violence victims to pursue their claims will give them a chance to experience greater justice. Having a court conduct a dignified proceeding about the domestic violence the victim has suffered conveys to the victim that it takes her and her harm seriously. The proceeding itself can assure the victim of her importance and that domestic violence is a serious matter. ${ }^{424}$

Opening up this field of litigation will affirm the unacceptability of domestic violence. After more tort claims are filed, courts will become accustomed to adjudicating such claims. This will encourage more attorneys to file domestic violence tort actions and create victim awareness of the benefits offered by these actions. If these tort claims become commonplace, they could alter abusive behavior throughout society. On the individual level, a tort suit or the threat of a tort suit could deter abusive conduct in individual relationships. We should aspire to create a new approach to the representation of domestic violence victims in which cases are frequently litigated, domestic violence victims are supported, and intimate partners engage in little or no abusive conduct.

\section{CONCLUSION}

It is time to bring tort law to the fore of domestic violence advocacy. Coverture, chastisement, and spousal immunity historically shielded abusers

\footnotetext{
424. Lind et al., supra note 360, at 981 (“[D]ignified procedures tend to provoke favorable responses because under them litigants feel that the court accords importance to the persons and subject matter involved in the dispute. Thus, for our tort litigants, the fact the court was willing to undertake a dignified hearing of the dispute may have constituted evidence that the civil justice system took the litigants and the dispute seriously. The fact that their case was deemed important enough to receive so respectuful a hearing was probably quite flattering. After all, the trial was in all likelihood one of the most meticulous, most individualized interactions that the litigant had ever experienced in the course of his or her contacts with government agencies.").
} 
from civil liability. Coverture and chastisement have been eliminated, and spousal immunity has been limited or abrogated in almost all states. Insurance policy exclusions and recalcitrant courts continue to pose obstacles to domestic violence tort suits. Domestic violence plaintiffs and their lawyers need to engage courts and the insurance industry to remove the remaining obstacles to domestic violence tort suits. States should legislate specific domestic violence tort causes of action, and courts should welcome novel domestic violence tort claims. Through increased attention to domestic violence tort law, we can overcome the vestiges of chastisement, coverture, spousal immunity, and outdated sexist courts.

Domestic violence victims are independent legal beings who can sue spouses and intimate partners for tortious domestic violence acts. Domestic violence torts have not been a predominate aspect of our laws or popular culture. Now that these archaic doctrines of gender discrimination have been removed, lawyers should bring these claims into the mainstream legal landscape. 